\title{
NOVÉ POZNATKY Z VÝSKUMOV HRADU SLANEC
}

\section{TOMÁŠ JANURA - RASTISLAV RUSNÁK - MICHAL ŠIMKOVIC - LUKÁŠ TRNKUS}

\begin{abstract}
Abstrakt: Hrad Slanec nechal postavit' Peter zo Slanca z rodu Aba pred rokom 1282. Vel'kú gotickú prestavbu niekedy medzi rokmi 1387-1395 inicioval Ladislav z Lučenca († 1395). V písomných prameňoch boli zistené zmienky o prestavbách hradu medzi rokmi 1521 a 1523 a jeho obnove po roku 1538. V̌́ase povstania Imricha Thökölyho Slanec zničili a spustol. K čiastočnej obnove ruiny došlo za grófa Jozefa Forgácha (*1763, † 1832), ktorý nechal v roku 1815 opravit'vežu.

Archeologický výskum sa sústredil najmä na jadro hradu. Podarilo sa odkryt' celý rad pozostatkov architektúr a dlážky v juhozápadnom trakte paláca. Prínosom pre poznanie stavebného vývoja hradu sú nálezy rôznych druhov stredovekej stavebnej keramiky, najmä tehál a dlaždic.

Architektonicko-historický výskum v rámci mladšieho stredovekého plášta zistil hmotu najstaršej veže. Veža bola ústrednou stavbou hradného areálu v s rozmermi $19 \times 15 \mathrm{~m}$ s menšou budovou na východnej strane. Archeologický výskum tiež upresnil dispozičné riešenie hradného paláca po gotickej prestavbe realizovanej po roku 1387.
\end{abstract}

Kl'účové slová: Slanec - hrad - veža - opevnenie - Ladislav z Lučenca-Jozef Forgách-Mikuláš Forgách.

\section{New Findings from Research into Slanec Castle}

\begin{abstract}
The Slanec castle was built by Peter of Slanec before the year 1282. Its major Gothic reconstruction in 1387-1395 was initiated by Ladislav of Lučenec († 1395). Another reconstruction confirmed by written sources started between the years 1521 and 1523, and renovation took place after 1538. During the uprising of Imrich Thököly Slanec sustained damage after which it was not restored. The ruin was partially reconstructed under Count Jozef Forgách (*1763, † 1832) who had the tower repaired in 1815.

Archaeological research centred on the castle core. A large number of remains of architecture as well as floor tiles were uncovered in the south-west wing of the palace. Information about the building development of the castle was also expanded by a wealth of finds of different kinds of medieval building ceramics, especially bricks and floor tiles.

The architectural research into the late medieval phase revealed masonry of the oldest tower. The castle tower was the central construction of the castle area in the shape of an almost regular rectangle of $19 \times 15 \mathrm{~m}$, with a small building in the eastern section. Archaeological research also specified the internal layout of the palace after its Gothic reconstruction executed after 1387.
\end{abstract}

Key words: Slanec-castle-tower-fortification-Ladislav of Lučenec-Jozef Forgách-Mikuláš Forgách.

\section{Úvod}

Východoslovenský hrad Slanec patrí vd’aka zachovaným zvyškom paláca a veže s množstvom vrcholnogotických detailov medzi naše najznámejšie hradné zrúcaniny. V rokoch 2012 a 2013 prebiehali na hrade prípravné práce na obnovu hradnej veže a konzerváciu ohrozených častí paláca. Zahŕňali podrobný architektonicko-historický výskum hradnej veže (M. Šimkovic), sondážny archeologický výskum paláca (R. Rusnák a L. Trnkus) a archívno-historický výskum dejín hradu (T. Janura). Uvedené výskumy významne prehĺbili doterajšie poznatky o stavebnom vývoji hradu. Vzhl'adom na skutočnost', že podrobný architektonický a archeologický výskum bude pokračovat' aj v nasledujúcich sezónach, v predloženom príspevku sú publikované predovšetkým výsledky celého archívno-historického výskumu. Tie sú doplnené o nové poznatky $\mathrm{k}$ architektúre stredovekého hradu zistené aktuálnym archeologickým a architektonicko-historickým výskumom.

\section{Doterajšie poznatky o architektúre hradu}

Hrad Slanec ako významná ruina so zachovaným množstvom architektonických detailov bol od 19. storočia predmetom pozornosti bádatel’ov. Dôležitým prameňom poznania hradu je kresebná dokumentácia, ktorú v roku 1878 spracoval Viktor Myskovszky. Obsahuje južný 
a severovýchodný pohl’ad na zrúcaninu, kótovaný pôdorys hradu, pôdorys veže po podlažiach, zvislý rez vežou a pohl'ad z juhovýchodnej strany. Zameranie zrúcaniny dopíňajú kresby vybraných detailov. $Z$ uvedených kresieb majú vysokú dokumentačnú hodnotu predovšetkým pôdorysy, rez a pohlad na vežu. $Z$ nich je možné identifikovat' usporiadanie veže po romantizujúcej prestavbe. Cenným prínosom sú tiež detailné kresby portálov veže a konzol klenby kaplnky s častou prípory. Tu však porovnanie so zachovanými článkami dokladá určitý stupeň zjednodušenia zobrazených prvkov.

Stavebný vývoj hradu Slanec bol niekol'kokrát spracovaný formou monografických štúdií a hesiel v rámci súborného spracovania hradov. Vzhl'adom na skutočnost', že vo výraze zrúcaniny je dominantná vrcholnogotická prestavba, pozornost' bádatel’ov bola sústredená predovšetkým na zachované gotické články a otázku ich datovania. Čiastočne sa architektúrou hradu zaoberali Václav a Dobroslava Menclovi, ktorí prestavbu Slanca zaradili do konca 14. storočia (Menclovi 1938, 379). V d’alšom súbornom spracovaní typológie hradnej architektúry Dobroslava Menclová datovala tvaroslovné prvky hradu do obdobia okolo rokov 1330-1340 a výstavbu hradu pripísala Drugethovcom (Menclová 1974, 409-410).

Prvým pokusom o komplexné spracovanie stavebného vývoja hradu je nepublikovaný materiál Zdeňka Gardavského (Gardavský 1971, nestr.). Za najstaršiu stavbu hradu určil trojpodlažnú obytnú vežu, ukončenú obrannou ochodzou s cimburím. Za súčast' veže považoval aj ranogotickú kaplnku. Gardavský predpokladal, že najstarší hrad bol opevnený palisádou. Do rozsiahlej neskorogotickej prestavby hradu datovanej po dobývaní hradu v roku 1480 radí nadstavbu pôvodnej veže a jej prebudovanie na hradný palác. Pri veži zároveň vznikla valcová veža, ktorá bola spolu s palácom ukončená okružnou ochodzou vysadenou na konzolách. Súčast'ou elaborátu je aj skica pôdorysu hradu, ktorá verne zachytáva dispozíciu hradu a jeho základné objekty.

Na Gardavského poznatky nadviazal M. Slivka (Slivka 1981, 119-127), ktorý vývoju hradu venoval samostatnú štúdiu. Slivka komplexne spracoval dejiny hradu, vrátane pravekého osídlenia okolitého územia. V rámci vývoja hradu akceptoval Gardavského koncepciu vývoja hradu s hranolovou obytnou vežou s kaplnkou ako najstaršou stavbou hradu.

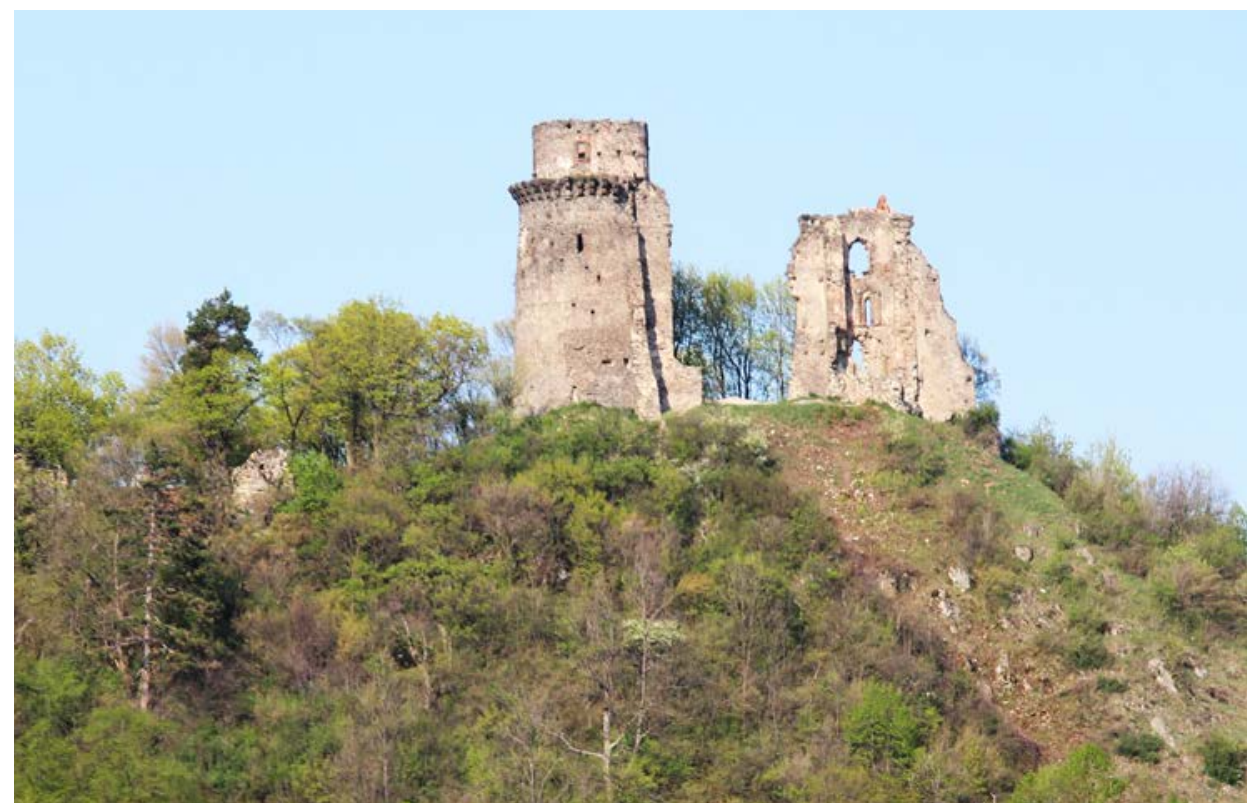

Obr. 1. Hrad Slanec, okr. Košice-okolie. Celkový pohl’ad na hrad od juhozápadu v roku 2012. Foto M. Šimkovic. Abb. 1. Burg Slanec, Bez. Košice-Umland. Gesamtblick auf die Burg von Südwesten im Jahr 2012. Foto M. Šimkovic. 
Mierne korigovaná verzia vývoja hradu je prezentovaná v rámci hesla publikácie venovanej súbornému spracovaniu hradov a hrádkov na východnom Slovensku (Slivka-Vallašek 1991, 196-198). Tu je prestavba pôvodného hradu spojená s vybudovaním paláca, okrúhlej veže a kaplnky datovaná na začiatok 14. storočia a je pripísaná bohatému rodu Drugetovcov. Do konca 15. storočia je datovaný vznik vonkajšieho opevnenia hradu.

Odlišný pohl'ad na stavebný vývoj stredovekého hradu publikoval M. Šimkovic v hesle spracovanom v rámci súborného spracovania gotického výtvarného umenia Slovenska (Šimkovic 2003, 594-595; Šimkovic-Bóna 2003, 201-202). V rámci vývoja hradu bol odlíšený pôvodný hrad z 13. storočia od neskoršej gotickej prestavby. Pôvodné sídlo z 13. storočia mala tvorit' nevel'ká dispozícia s valcovou vežou v čele, obvodovou hradbou s cimburím a obytnou budovou krytou za hradbou na chránenej severovýchodnej strane. Vrcholom stredovekého vývoja hradu mala byt' vrcholnogotická prestavba, z ktorej pochádza väčšina zachovaných architektonických článkov. Predstavuje zásadnú premenu hradného jadra na vel'ký hradný palác s kaplnkou, ktorý sa pripojil k veži tak, že obe stavby splynuli do jedného celku. Veža bola na vonkajšej strane oplášt’ovaná a zvýšená o dve podlažia. Nový pohl'ad na stavebný vývoj hradu priniesol aj zmenu datovania gotickej prestavby, ktorá bola zaradená do konca 14. storočia, ked' hrad získal Ladislav z Lučenca.

Naznačený vývoj hradu akceptoval aj M. Plaček (Plaček-Bóna 2007, 263-265) v rámci príslušného hesla v Encyklopédii slovenských hradov.

\section{Historické pramene k dejinám hradu}

Za prvú nepriamu písomnú zmienku o území, na ktorom neskôr vznikli hrad a dedina Slanec, sa považovala nedatovaná listina král’a Ladislava IV. (MNL - OL, DL 867). V texte listiny sa uvádza, že územie Saranca (terra Saranca) bolo vyčlenené z majetkov sídelného stoličného hradu Abaujvár (dnes v Mad’arsku) a darované Šalamúnovi, synovi Gabriela. Šalamún si král’ovskú donáciu zaslúžil za hrdinské vojenské činy pri vyhnaní českých vojsk Přemysla Otakara II. z hradu Ráb (Győr; dnes v Mad’arsku) v roku 1270, počas sporov o babenberské dedičstvo s uhorským králom.

Z hladiska neskorších dokumentov dokladajúcich vlastnícke pomery na hrade Slanec možno vyslovit’ domnienku, že pod názvom Saranca sa môže skrývat' úplne iná lokalita. Je potrebné si uvedomit', že hrad Slanec patril slanskej vetve rodu Aba a zatial' neexistuje žiadny doklad, že by spomínaný Šalamún patril k príslušníkom tohto vplyvného rodu. Inou možnostou je, že Šalamún neskôr územie Saranca prenechal slanskej vetve rodu Abovcov, o čom sa nezachovala žiadna písomná správa.

V porovnaní s neskoršími priamymi písomnými dokumentmi z roku 1282 a 1303 možno plne súhlasit's tvrdením Pála Engela, že hrad Slanec nechal postavit' Peter zo Slanca, zakladatel' slanskej vetvy rodu Aba, pred rokom 1282 (Engel 1996, heslo Szalánc). Základným argumentom podporujúcim výstavbu hradu Petrom zo Slanca je del'ba majetkov slanskej vetvy v roku 1303. Synovia a vnuk sa nechceli sporit' o užívanie zatial' nerozdelených majetkov svojho otca i starého otca, ktoré od výstavby hradu Petrom zostávali spoločné. Ak by totiž hrad vznikol až v ich generácii, $\mathrm{v}$ listine by sa to určite zdôraznilo.

Prvýkrát sa o existencii hradu Slanec píše v bližšie nedatovanej listine král'a Ladislava IV. z roku 1282 (MNL - OL, DL 90810). Panovník vtedy daroval zem Léh v Turnianskej stolici komesovi Guentyrovi, synovi Oroda de Kynis. Guentyr sa zúčastnil viacerých vojenských král'ovských výprav a svoju vernost' osvedčil pod hradmi Sárospatak (dnes v Mad’arsku) a Slanec (Zalanch). Guentyr obzvlášt' hrdinsky bojoval pri dobýjaní Slanca až dovtedy, kým ho viacero kameňov nezranilo a nezačala mu tiect' krv. Majitelia Slanca sa v uvedenom roku postavili na stranu vzbúreného palatína Fintu z inej rodovej línie Abovcov.

Prvá zmienka o majitel'och hradu sa zachovala až z 8. októbra 1303, ked' vznikla del'ba panstva Slanec (RDSL I, 128 č. 242). Majetok si medzi seba rozdelili na jednej strane komes Michal a Peter, synovia spomínaného medzičasom zosnulého Petra zo Slanca (de Zalanch), a na druhej 
strane Ladislav, syn nebohého Vavrinca, ktorý bol bratom spomínaných Michala a Petra. Michal a Peter získali hrad Slanec, dediny Slanec a Olšovany, aj polovicu Durkova od dediny Svinica. Ladislav sa musel uspokojit's dedinou Ruskov a druhou polovicou Ďurkova od hradu Slanec.

Zo spomínanej listiny je zrejmé, že príslušenstvo hradu tvorili iba štyri dediny, čo sa podpísalo na nevel'kej rozlohe opevneného sídla. Malé panstvo nemohlo zabezpečit' dostatok prostriedkov na výstavbu rozsiahlejšieho hradného areálu na konci 13. storočia. Až po založení nových dedín v 14. storočí a príchode bohatého rodu z Lučenca (Lossonczy) bolo možné použit’ prostriedky aj z iných zdrojov na rozšírenie či prestavbu, ako iba príjmy samotného hradného panstva.

Šlachtický rod zo Slanca sa na ním vybudovanom hrade dlho nezdržal. Po bitke pri Rozhanovciach v roku 1312 už spomínaný Peter zo Slanca a Vavrinec, syn spomenutého nebohého Vavrinca zo Slanca, vstúpili do služieb Viliama Drugetha, ktorý z nich urobil kastelánov na svojich hradoch Spiš a Dunajec. V roku 1329 požiadali Peter zo Slanca, Vavrinec zo Slanca a d’alší príbuzní o vydanie staršej listiny o del'be hradného panstva Slanec. O tento dokument požiadali v súvislosti s nadchádzajúcou majetkovou zámenou, ktorá sa udiala bud' v roku 1329, alebo 1330 (AO XIII, 100, 296, 297 č. 159, 488, 489).

V rokom neurčenej listine, historikmi datovanej do roku 1330 na základe uvedených cirkevných hodnostárov, sa písalo o stretnutí spišského a abovského župana Viliama Drugetha so spomenutým komesom Petrom zo Slanca a komesom Vavrincom zo Slanca. Obe strany sa zišli pred jágerskou kapitulou, aby potvrdili dohodnutú výmenu majetkov. Uvedení členovia rodu zo Slanca, slúžiaci ako kasteláni na drugethovských hradoch, sa v prospech Drugetha vzdali celého hradného panstva Slanec a Drugeth im na oplátku daroval nasledovné dediny v Šarišskej stolici - Bertotovce, Hendrichovce, Fričovce a Široké (AO XIV, 354, 356, 357 č. 624, 630).

Magister Viliam Drugeth nechal 9. augusta 1330 na hrade Šariš napísat' svoju poslednú vôl'u (AO XIV, 285, 286 č. 473). V testamente ustanovil za dediča hradov Slanec, Parič, Brekov, Jasenov, Plaveč, L’ubovňa, Sokol' a Dunajec, ktoré získal dedične, kúpou alebo zámenou, svojho brata Mikuláša Drugetha. V rámci drugethovských panstiev tvoril hrad Slanec spoločnú správnu jednotku so susedným panstvom Parič. Tento stav potvrdila listina z roku 1335 (AO XIX, 354 č. 787), ked’ sa spomínal magister Gál, syn Juraja, ako kastelán na hradoch Slanec a Parič.

Po smrti Viliama Drugetha v roku 1342 sa Slanec stal král’ovským majetkom, nakol'ko nemal mužského potomka a z hl'adiska uhorských zákonov mali jeho majetky pripadnút' korune. Královský hrad potom do poslednej tretiny 14. storočia panovník udel'oval „,pro honore“ abovským županom. To znamenalo, že v čase výkonu svojej funkcie mali užívacie právo na panstvo Slanec. Iba jediný zo županov zastával zároveň aj post slanského kastelána.

V rokoch 1343-1360 sa slanským kastelánom a zároveň abovským županom stal magister Peter, zvaný Pohárnik. Ten dostal svoju prezývku podl'a toho, že na dvore král’a Karola Róberta zastával funkciu pohárnika. Peter sa počas svojho života zdržiaval predovšetkým na král'ovskom dvore, a preto musel vymenovat' podkastelána na Slanci, aby niekto reálne spravoval hradné panstvo. Petrov podkastelán Ján sa osobne so svojím pánom zúčastnil výpravy Karola Róberta proti Benátkam. Po smrti Karola Róberta ostal Peter slúžit' aj jeho synovi L'udovítovi I. Vel'kému. Ako jeho dvorský rytier získal funkciu král’ovského prokurátora (MNL - OL, DL 64051; AO XXXI, 508 č. 991).

Po smrti Ludovíta I. dochádza v celom král'ovstve k postupnému rozdel'ovaniu rozsiahleho král'ovského majetku, čo je aj prípad hradu Slanec, postupne odovzdaného šlachticom z Lučenca (de Losonch). Najprv 24. januára 1386 král' Karol II. a královná vdova Alžbeta vydali dve listiny (BO I, 378, 379 č. 270, 271), ktorými darovali svojmu dvorskému rytierovi Ladislavovi z Lučenca $(\dagger 1395)$ dedinu Novosad v Zemplínskej stolici, patriacu ku královskému hradu Slanec. Pri udelení donácie zavážilo, že Ladislav stál po smrti král’a L’udovíta I. neochvejne na strane král'ovnej vdovy a v bojoch o trón podporoval král’a Karola II. i v nepriaznivých časoch.

Po zavraždení Karola II. Ladislav z Lučenca prestúpil na stranu Žigmunda Luxemburského a začal bojovat' proti jeho nepriatel'om. Zúčastnil sa oslobodzovania zajatej král'ovnej Alžbety vdovy a král'ovnej Márie, Žigmundovej manželky. Vojská pod Ladislavovým velením oslobodili po zavraždení Alžbety jej dcéru Máriu a dopravili ju k Žigmundovi. Za tieto zásluhy Ladislava 
menovali za severínskeho bána. Ôsmeho júla 1387 (BO I, 403, 404 č. 288) král' odmenil Ladislava dedinami Kašov a Hraň, ktoré dovtedy patrili ku král'ovskému hradu Slanec.

Ladislavovi z Lučenca bola najviac povd’ačnou samotná král’ovná Mária, ktorá mu so súhlasom popredných mužov král’ovstva a král’a Žigmunda 25. júla 1387 udelila král’ovský hrad Slanec s panstvom do dedičného vlastníctva (BO I, 406, 407 č. 290). Pri odôvodnení donácie pripomenula, že Ladislav od svojej mladosti slúžil verne na král’ovskom dvore a zaslúžil sa o jej vyslobodenie z väzenia na Novom Grade v Dalmácii.

Neskôr Ladislava z Lučenca vymenovali za mačvianskeho bána a ešte pred 24. augustom 1387 leleský konvent vykonal štatúciu na nadobudnuté panstvo Slanec (ZsO I, 19 č. 198). Vrchol Ladislavovej kariéry predstavovalo menovanie za slavónskeho bána. Pre Ladislava bolo získanie prvého vel'kého hradného panstva impulzom k vel'kým stavebným zmenám, nakol'ko sa Slanec stal jeho sídlom. Na základe uvedených skutočností Ladislav poznal z osobnej skúsenosti vyspelú gotickú svetskú architektúru král’ovského anjouovského dvora a nakol'ko nemal k dispozícii iné hradné sídlo, nechal Slanec prestavat’ vo vyspelom gotickom architektonickom výraze.

Po otcovej smrti sa novým majitelom hradu stal jeho dospelý syn Žigmund z Lučenca († 1434/1435), ktorého 6. októbra 1398 leleský konvent štatuoval do držby panstva (BO I, 468 č. 334). Žigmund pokračoval v stopách svojho otca a zaradil sa k verným stúpencom Žigmunda Luxemburského. Počas bojov krála proti moravskému markgrófovi Joštovi, ktorý vtrhol na západné územie Uhorska, sa Žigmund vyznamenal spolu so svojimi familiármi. Spoločnými silami vyhnali markgrófa z krajiny a prenasledovali ho na Moravu, kde ho aj zásluhou Žigmunda porazili pri meste Chotěboř. Za odmenu král' Žigmund 9. júna 1405 udelil novú donáciu pre Žigmunda z Lučenca na hrady Dezna a Pâncota v stolici Zaránd (dnes v Rumunsku) a hrad Slanec v Abovskej stolici a dedinu Novosad v Zemplínskej stolici (BO I, 486 č. 350). V dodatku darovacej listiny uviedli, že všetky tri hrady sa stali vlastníctvom aj Žigmundovho brata Dionýza z Lučenca († 1426/1427).

Získanie dvoch hradných panstiev v Sedmohradsku a prevzatie hradu Halič po bezdetnom strýkovi Štefanovi z Lučenca poznačilo d’alšie osudy hradu Slanec, ktorý sa s narastaním majetkovej domény pánov z Lučenca dostal postupne mimo centra pozornosti rodových členov uprednostňujúcich iné sídla. Vd’aka tomu sa mohla zachovat' takmer autentická podoba z čias vel'kolepej gotickej prestavby. Žigmund z Lučenca sa zdržiaval predovšetkým na sedmohradských majetkoch, nakol'ko zastával funkciu severínskeho kapitána a Dionýz z Lučenca zostal sídlit’ na Slanci.

Po Dionýzovej a Žigmundovej smrti Slanec prešiel do rúk bezdetného Ladislava z Lučenca († 1439), syna Žigmunda, a bratov Jána z Lučenca a Alberta z Lučenca († 1466). Obe strany mali na hrade vlastného kastelána, čo doložila listina z 9. mája 1437 (MNL - OL, DL 90884). Na základe genealogických údajov a informácií o zisku d’alších panstiev sa dá predpokladat', že Ladislav obýval Slanec, sedmohradské hrady sa stali obydlím sabolčského župana Jána a v Haliči sa usadil novohradský župan Albert.

Okolo polovice 15. storočia sa jediným majitel’om hradu vd’aka úmrtiu ostatných príbuzných stal Albert z Lučenca (MNL - OL, DL 14384). Po Albertovej smrti sa majitel'mi hradu stali jeho dvaja synovia Ladislav Lossonczy (de Lossoncz; $\uparrow 1498$ ) a bezdetný Štefan Lossonczy († 1479). Ešte počas svojej mladosti sa Ladislav pravdepodobne zdržiaval na Slanci (BO II, 218, 219 č. 181). Štefan sa pravdepodobne zdržiaval najčastejšie v kaštieli Sečany, nakol'ko zastával pozíciu král'ovského stolníka a toto panstvo sa nachádzalo ned’aleko budínskeho dvora. Ladislav sa v druhej polovici života zdržiaval predovšetkým na dvore v Budíne alebo na majetkoch v Sedmohradsku, nakol'ko zastával post taverníka (MNL - OL, DL 27077) a sedmohradského vojvodu (MNL - OL, DL 82065).

Po smrti Ladislava Lossonczyho zdedili hrad jeho dvaja synovia Žigmund Lossonczy († pred 1523) a bezdetný Albert Lossonczy († 1506), ktorý si pravdepodobne vybral za sídlo Sečany. Žigmund spočiatku pôsobil ako cirkevný hodnostár vo funkcii prepošta starobudínskeho kostola - preto nevyužíval žiadny z hradov ako svoje sídlo. Správu panstva Slanec vtedy vykonávali dvaja hradní kasteláni (BO II, 399 č. 321). Po smrti brata Alberta sa Žigmund ako posledný žijúci člen rodu Lossonczy oženil a postaral sa o jeho pokračovanie. 
Žigmund Lossonczy bol vlastníkom banderiálneho vojska, s ktorým bojoval proti postupujúcim Osmanom. V priebehu rokov 1514 a 1515 využil vlastné bandérium na potláčanie povstania Juraja Dóžu. Práve v tom čase sa na Slanci dočasne zdržiavala jeho manželka Katarína Dóczyová. Žigmund v liste zo svojho hradu Ineu (dnes v Rumunsku) z 30. septembra 1515 píše svojmu kastelánovi na hrade Slanec Jurajovi Chapy, aby sa dobre postarali o jeho manželku a nič jej nechýbalo (MNL - OL, DL 82439).

Žigmund Lossonczy správu panstva riadil prostredníctvom kastelána Juraja Chapyho. Kastelánovi zveril aj prestavbu hradu, ktorá sa začala $\mathrm{v}$ čase pred Žigmundovou smrtou, niekedy medzi rokmi 1521 a 1523. Prestavbu Slanca ukončili až za vdovy Kataríny Dóczyovej, ktorá ju riadila opät' prostredníctvom kastelána Chapyho, nakol'ko sa na hrade nezdržiavala. Katarína 13. mája 1523 napísala Chapymu list, aby zaobstaral všetko potrebné na prebiehajúce stavebné práce. V súvislosti s dokončením stavby cisterny, ktorú začal ešte jej manžel, ho upozornila, aby žiadni poddaní nepracovali pri kamenárskych prácach. Tie sa majú zaplatit' určenými peniazmi. Ďalej spresnila, ako sa majú jednotliví poddaní podiel'at' na obnovovaní (preložitel'né aj ako uvedení do pôvodného stavu) hradu (MNL - OL, DL 82483, DL 82606).

Po smrti Žigmunda Lossonczyho došlo pravdepodobne k del'be majetkov medzi jeho synmi, ktorú sa zatial' nepodarilo písomne podložit'. Panstvá na území východnej časti Horného Uhorska a Sedmohradska pripadli s vel'kou pravdepodobnost'ou Štefanovi Lossonczymu († 1553) a jeho brat Anton Lossonczy asi nadobudol domíniá v strednej a západnej časti Horného Uhorska. Štefan Lossonczy sa v prvej polovici života zdržiaval na hrade Slanec a po bitke pri Moháči sa postavil na stranu Jána Zápol'ského. Zo Slanca podnikal lúpežné výpravy na majetky mesta Košice. V prepadoch neskončil ani po uzavretí Vel'kovaradínskeho mieru. Ferdinand I. tak musel vyslat' svojho hlavného pohárnika Antona Lossonczyho za Jánom Zápol'ským, aby donútil Štefana skoncovat' s prepadávaním cudzieho majetku. Po uzavretí mieru Ferdinand I. Slanec skonfiškoval a odovzdal ho do rúk Antona. Ten dal hrad rozbúrat'. Všetky uvedené informácie sa spomínali v listine z 19. augusta 1538 (PO III, 38, 39 č. 14).

Poslednou žijúcou príslušníčkou rodu Lossonczy sa stala Anna Lossonczyová († 1595), dcéra Štefana Lossonczyho, na ktorú prešli všetky uhorské rodové majetky - hrady Topol'čany v Nitrianskej, Šomoška a Sečany v Novohradskej a Slanec v Abovskej stolici; kaštiele Halič v Novohradskej, Hraň v Zemplínskej a Szent Márton (dnes v Mad’arsku) v Sabolčskej stolici. K tomu patrili aj tri sedmohradské hrady Ineu, Dezna a Pâncota v stolici Zaránd. Na základe testamentu Anny Lossonczyovej z 11. apríla 1593 (MNL - OL, LRa) sa so súhlasom krála dedičom polovice panstva Topol'čany stal jej druhý manžel, novohradský župan barón Žigmund Forgách (* 1560, † 1621). Po smrti Anny testament v roku 1596 potvrdil Rudolf II. (MNL - OL, P 287a). Ostatné lossonczyovské majetky zostali v rukách Uhorskej komory ako odúmrt', ale dočasne v Žigmundovej správe.

Okrem polovice panstva Topol'čany sa v roku 1596 podarilo Žigmundovi Forgáchovi získat' do osobného vlastníctva aj panstvo Slanec s pridruženým panstvom kaštiel’a v Hrani. Medzi 20. júnom a 16. júlom 1596 sa uskutočnil súpis všetkých prináležitostí Slanca a Hrane. K hradnému panstvu patrili na území Abovskej stolice celé dediny Slanské Podhradie (dnes miestna čast' Slanca) s majerom, Regeta (dnes miestna čast' Slančíka), Pusztafalu, Rákoš, Slančík, Slanské Nové Mesto, Ruskov, Nadaska a podiel v dedine Nižný Čaj. V Zemplínskej stolici k Slancu patrila celá dedina Hraň s kamenným kaštiel’om, zemepanské mesto Novosad a celá dedina Kašov pri Hrani (MNL - OL, UCa).

Pre Žigmunda Forgácha, zdržujúceho sa na území novohradských majetkov nebohej manželky, nepredstavoval Slanec pre svoju vzdialenost' významnejšie panstvo. Preto ho v roku 1599 za poskytnutie finančnej pôžičky 12000 uhorských zlatých do času vyplatenia dlžnej sumy prenechal radcovi Spišskej komory Jurajovi Hoffmanovi. Svedectvo o prevode panstva vydala Jágerská kapitula 26. mája toho istého roku (MNL - OL, P 287b).

Udelenia lossonczyovských sídiel a príslušných panstiev Topol’čany, Halič, Sečany, Šomoška, Slanec, Hraň a Szent Márton sa královský radca a novohradský hlavný župan Žigmund Forgách dočkal 7. júna 1601. Rudolf II. ich Žigmundovi dočasne prenechal za zaplatenie sumy 
67389 uhorských zlatých. Zároveň za d’alších 40000 uhorských zlatých nadobudol dedičské užívacie právo aj na sedmohradské hrady Ineu, Dezna a Pâncota. O tri roky už Rudolf II. 7. apríla 1604 vydal pre Žigmunda Forgácha donáciu, na základe ktorej sa stal dedičným vlastníkom všetkých spomenutých lossonczyovských majetkov (MNL - OL, LRa).

Žigmund Forgách sa vd’aka rodovým i vyženeným majetkom stal jedným z najbohatších magnátov svojej doby. Vrchol jeho kariéry predstavovalo získanie postu uhorského palatína. Hlavným sídlom sa stal ním postavený honosný kaštiel' v Haliči. Prvého septembra 1620 Žigmund napísal na Haliči svoj testament. V poslednej vôli ustanovil rozdelenie majetku medzi svojich dvoch synov. Starší syn Adam st. Forgách $(* 1601, \dagger 1681)$ získal dolnouhorské panstvá Gýmeš, Topol’čany, Komjatice, Halič a Šomoška. Mladší syn Žigmund Ján Forgách (* 1605, † 1645) dostal hornouhorské majetky Hertník, Šebeš, Slanec, Hraň, Szent Márton, Aszaló a Ond (obe lokality v Mad’arsku). Panstvo Sečany pripadlo dcéram Márii Františke a Alžbete Forgáchovým (MNL - OL, P 287a).

Žigmund Ján Forgách využíval ako obytné stavby predovšetkým kaštiele v Hertníku, Nižnej Šebastovej a Hrani. Zdržiaval sa tu spolu s manželkou, grófkou Barborou Batthyányovou († 1680). Manželia mali iba dcéru Máriu Alžbetu Forgáchovú, preto sa grófka Barbora po manželovej smrti stala správkyňou celého hornouhorského majetku. V čase povstania Juraja I. Rákócziho využívala Barbora hrad Slanec ako bezpečné útočisko a nechala tu uložit' svoje súkromné predmety a klenoty (MNL - OL, P 287c). Inak sa v mierových časoch najčastejšie zdržiavala v spomínaných manželových kaštiel'och.

Švagor grófky Barbory Batthyányovej Adam st. Forgách sa obával, aby sa prostredníctvom Barbory nedostal značný majetok z rodu. Na základe vzájomnej dohody z 26. mája 1655 sa ustanovilo, že vdova Barbora dostala do užívania hrad Slanec, kaštiele Hertník, Nižná Šebastová a Szent Márton (MNL - OL, LRb). K tomu dostala zemepanské mesto Aszaló s vinicami v Boršodskej stolici. Užívacie právo sa vzt’ahovalo na celé obdobie jej vdovského stavu. Súčastou dohody nebol kaštiel' v Hrani, ktorý sa stal Barboriným osobným vlastníctvom (MNL - OL, P 287d).

Z čias užívania Slanca grófkou Barborou Batthyányovou sa zachoval zatial' jediný známy bližší popis interiérového členenia hradu. Inventár hradu bol súčast'ou rozsiahleho súpisu vdovských majetkov, vykonaného od 8. do 11. novembra 1672. Samotný hrad Slanec zapisovatelia navštívili 9. novembra a tvorili ho nasledovné miestnosti a priestory - „dolná palota horného hradu“ so zástavami a kopijami, dreveným koňom, trúbkou, skriňou so ženským oblečením a siedmimi nemeckými knihami, postel'nou bielizňou, zelenou skriňou a obrazom; „susedný sklep“ (teda zaklenutá miestnost', nie pivnica) so šiestimi poškodenými koženými kreslami a jedným purpurovým; ,rohový sklep“ s piatimi väčšími truhlicami s plátnovými vecami a obrusmi, ôsmimi bielymi sklenenými flašami; , ,rohová svetlica (dom)“ s dvomi obrazmi manželov Žigmunda Jána Forgácha a Barbory Batthyányovej, dvomi stolmi potiahnutými zeleným súknom, prázdnou lekárnickou skrinkou; „susedná palota“ s piatimi kopijami, desiatimi kreslami, ženskými šatami, príborníkom, dvomi stolmi, tromi obrazmi; „pitvor paloty“ so šiestimi medenými tabul'ami, jednou poškodenou sklenenou lampou; ,zbrojnica“ so 48 sakálošmi alebo bombardami, 31 mušketami, tromi starými puškami, rôznorodou muníciou; priestor „vedl’a zbrojni-

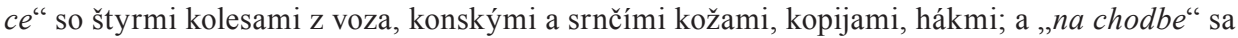
skladovalo obilie. Za tým sa prechádzalo do priestorov pod strechou.

Druhou stranou potom zostupovali zo strešných priestorov smerom dole. V „lekárni“ boli viaceré fl'aštičky na medikamenty. V „obilníkovej svetlici (dome)“ bolo sedem misiek, železá na pečenie, dva stoly. V „susednom sklepe“ sa nachádzalo dvanást’ obrazov, štyri purpurové stoličky modrej farby, dve červené a dve pergamenové snehobiele stoličky, jedna schránka na účty, tri schránky na písomnosti a knihy, dvanást' kožených pozlátených tapiet, pät' mal'ovaných tapiet, dve flámske tapety (asi gobelíny), drevené misy a taniere, jeden stupňovitý pulpit. V ,jedálni““ bola prázdna presklená skriňa a obilie, v „puškárovej svetlici (dome)“ sanitra, v „krajčírovej svetlici“ obilie, v „,komorníkovej svetlici“ d’alšie obilie, vo „vel'kej palote“ šindel', v „kaplnke“ sušené ovocie, v „hradnej bráne“ pätnást' muškiet a v „krajčirovom sklepe vedl'a jeho svetlice“ konope a sušené ovocie. V „dlhej pivnici“ boli sudy s vínom, podobne ako v „susednom sklepe, 
šafárovej pivnici, za šafárovou pivnicou, octovej pivnici, jej susednej pivnici a vel'kej pivnici horného hradu“. $\mathrm{Na}$,dolnom opevneni" rozmiestnili dve a štyri železné bronzové kolubríny, dve húfnice (seregbontó) a dva bronzové mažiare (MNL - OL, UCb).

Jedenásteho novembra 1672 prišla súpisná komisia do kaštiel’a v Hrani, ktorý však pre zradu panovníka pripadol král'ovskému fišku. Inventár kaštiel'a svedčil o tom, že tento objekt bol trvalejším sídlom grófky Barbory Batthyányovej, nakol'ko jeho priestory boli bohatšie zariadené a ich funkčné využitie vypovedalo o prítomnosti aristokratky (MNL - OL, UCb).

Po smrti grófky Barbory Batthyányovej sa hrad Slanec dostal v čase povstania Imricha Thökölyho do rúk detí Barborinho švagra, grófov Adama ml. Forgácha $(* 1663, \uparrow 1716)$ a jeho brata grófa Šimona Forgácha $(* 1669, \dagger 1730)$. V čase prechodu povstalcov bol hrad Slanec rozbúraný a ostal opustený ako odplata za vernost' oboch bratov cisárskej strane. Majetky bratov Forgáchovcov skonfiškovala povstalcami ovládaná Spišská komora. Pri tej príležitosti jej úradníci vytvorili 18. októbra 1682 súpisy majetkov panstva (MNL - OL, UCc).

Po druhýkrát Forgáchovci stratili panstvo Slanec a ostatné hornouhorské majetky v prvej polovici roku 1691 za obvinenie zo spolupráce s Imrichom Thökölym. Úradníci komory 21. augusta 1691 vyhotovili súpis panstva Slanec, patriaceho Adamovi ml. a Šimonovi Forgáchovcom za účast' na nedávnom povstaní. Pri opise hradu napísali, že v predošlých nepokojných časoch ho rebeli vypálili a od tých čias ostal opustený a nikým neobývaný. Vd’aka nepriaznivým poveternostným podmienkam sa stavby a múry hradu postupne rozpadávali a ničili (MNL - OL, $\mathrm{UCb}$ ).

Komora vzápätí skonfiškované panstvo Slanec poskytla za 10000 uhorských zlatých Štefanovi Szirmayovi. Ak chceli bratia Forgáchovci hornouhorské rodové majetky spät', vrátane Slanca, museli v roku 1694 zaplatit' 21600 zlatých uhorskej komore (MNL - OL, UCd, UCe). Ani jeden $\mathrm{z}$ forgáchovských bratov nemal v záujme usadit' sa na majetkoch, vzdialených od pohodlných rezidencií v Hlohovci a Haliči. Z toho dôvodu Adam ml. Forgách aj v zastúpení svojho brata Šimona Forgácha 22. apríla 1694 podpísal dohodu (MNL - OL, LRc), na základe ktorej panstvá Hertník, Nižná Šebastová a Slanec prenechal v dočasnej držbe za 30000 rýnskych zlatých viedenskému dvoranovi, radcovi Uhorskej a Spišskej komory, grófovi Ladislavovi Szent-Iványovi $(* 1656, \uparrow 1713)$.

Až v 60. rokoch 18. storočia (MNL - OL, P 287b) začal postupne panstvo Slanec vykupovat' od jednotlivých záložných majitel’ov ich vyplácaním nitriansky župan, cisársko-královský radca a komorník gróf Mikuláš Forgách (* 1731, † 1795). Po smrti bezdetného Mikuláša sa vlastníctvo Slanca dostalo do rúk syna Mikulášovho bratranca - grófa Jozefa Forgácha (* 1763, † 1832). Jozef nechal v roku 1815 opravit’ vežu Slaneckého hradu a osadit’ nápisovú tabulu. Gróf sa v Slanci neusadil a zdržiaval sa hlavne v kaštieli v Sečanoch.

Po Jozefovi zdedil slanecké panstvo jeho syn gróf Mikuláš Forgách (*1784, † 1857). Mikuláš sa usadil v Slanci, kde dal klasicisticky prestavat' starší barokový kaštiel' pod hradnou zrúcaninou a zriadit' park. Bez bližších písomných podkladov možno vyslovit' hypotézu, že práve pri zriad’ovaní parku do neho začlenili aj hrad ako romantickú zložku. Mikuláš v kaštieli pod hradom aj zomrel. Po Mikulášovej smrti sa kaštiel' a opravená veža stali vlastníctvom vnuka Mikulášovho brata - slobodného a bezdetného grófa Štefana Forgácha $(* 1854, \dagger 1916)$. Štefan sa v kaštieli narodil a aj zomrel, a bol posledným príslušníkom rodu Forgách, ktorý sa staral o hradnú vežu.

\section{Výsledky archeologického výskumu}

Archeologická sezóna 2013 na hrade Slanec už prebiehala paralelne so stavebnými prácami, ktoré súviseli s plánovanou postupnou revitalizáciou viacerých hradných architektúr. Výskum realizoval AÚ SAV. V programe obnovy bola sezónnou prioritou hradná veža. S tým bola spojená inštalácia konštrukcie lanovky do jej juhovýchodného susedstva kvôli transferu stavebného materiálu. Vrcholové stanovisko lanovky ústilo do priestoru niekdajšieho paláca. Sanácia jeho zachovaných architektúr stála v rade priorít hned' za vežou. Zároveň bolo v tomto priestore možné nadviazat' na prebiehajúci stavebno-historický výskum hradu (Šimkovic-Janura 2012), archeologické 
práce boli preto vnímané ako možnost' jeho vhodného doplnenia. Popritom sa v priebehu sezóny realizovalo ešte niekol'ko najnutnejších stavebných sanácií murív v iných častiach hradu kvôli ich zlému statickému stavu. Všetky tieto práce si vyžiadali realizáciu archeologických sond (obr. 2). Boli však rozsahom malé a neprekročili charakter základného archeologického ošetrenia danej situácie. Na komplexnejšie riešenia stavebného vývoja hradu mimo jeho jadra ešte nemožno stav výskumu považovat' za dostatočný, preto mu nevenujeme pozornost' ani v rámci tohto príspevku.

Ked’že palác je po veži nasledujúcou prioritou revitalizácie hradného areálu, sezóna 2013 bola i z archeologického hladiska výzvou pre lepšie zorientovanie sa v jeho stavebnom vývoji, identifikácii priebehu murív bez zachovaných nadzemných častí a tiež dobových pochôdznych úrovní. V priestore paláca bola postupne realizovaná sonda $1 / 13$, rozdelená na sektory $\mathrm{A}, \mathrm{B}$ a $\mathrm{C}$, doplnená ešte o rezy R1 a R2, tiež sonda $9 / 13$ a čiastočne i sondy 3/13 a 12/13. Sutinové zásypy paláca sa v týchto miestach nenachádzajú, pravdepodobne boli odstránené pri poslednej stavebnej fáze hradu, adaptácii veže na rodinné múzeum v 19. storočí. Pásová sonda 1/13 sa vinula celým interiérom paláca od múru mladšej prístavby schodiska veže až po juhovýchodnú obvodovú palácovú stenu. Konfigurácia terénu a vnútorné dispozičné riešenie paláca prirodzene rozdelilo

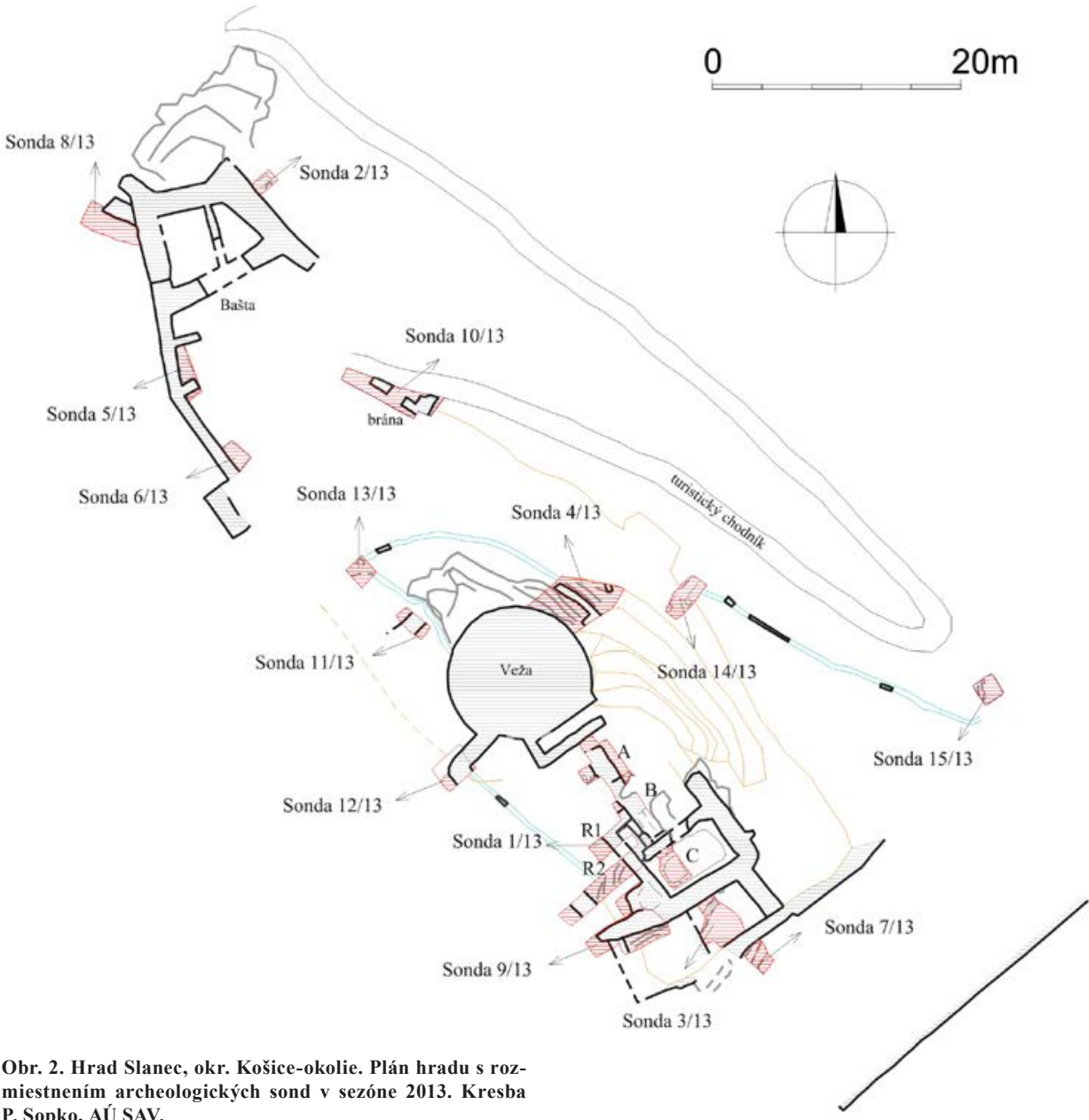

Abb. 2. Burg Slanec, Bez. Košice-Umland. Planskizze der Burg mit Verteilung der archäologischen Sondiergrabungen in der Saison 2013. Zeichnung P. Sopko, AÚ SAV. 
sondu na tri sektory $(1 \mathrm{~A}, 1 \mathrm{~B}, 1 \mathrm{C})$. Na viacerých miestach vystupovalo nad trávnatý terén skalné podložie, delilo i sektory 1A a 1B. Sonda 1/13 a dva na ňu kolmé rezy R1 a R2 odkryli celý rad pozostatkov kamenných, prípadne kamenno-tehlových architektúr (obr. 3). Viaceré z nich predstavovali už iba jeden až dva rady kameňov nad skalným podložím. Miera odstránenia pôvodných stratigrafických súvislostí bola v tomto priestore značná. Pochopenie a vyhodnotenie vzájomných vzt’ahov viacerých murív bolo možné len vd’aka úzkej spolupráci s realizátorom stavebno-historického výskumu. Relatívne hustá splet' murív zachytených najmä v sektore 1B a rezoch R1 a R2 doložila postupný vývoj zástavby v priestore paláca (obr. 18:M1, M4a, M5 a M6). Odhalila pravdepodobne zvyšky staršej budovy (obr. 18:M1) a neskoršiu priečku medzi severovýchodným a juhozápadným traktom paláca (obr. 18:M4a). Mladšia je iste i d’alšia priečka a jej fragmentárne zachytená rozšírená čast' (obr. 18:M5). Nálezové situácie murív v archeologických sondách sú vyhodnotené v rámci architektonicko-historického vyhodnotenia výskumu.

Sektor 1C/13 odkryl priestor, s vel'kou pravdepodobnost'ou vysekaný do skalného podložia, so stenami vybudovanými prevažne z tehál, iba miestami prekladanými lomovým kameňom (obr. 4, 18:M4b). Nárožia stien boli zaoblené. Pravdepodobne i podlahu odkrytého priestoru pôvodne tvorila tehlová dlažba, ukladaná do maltového lôžka na skalnom podloží odsekanom do roviny. Zachovala sa fragmentárne iba pri stenách. Tehly majú obdížnikové formáty s jemnou kanelúrou.

Rez R2 sondy $1 / 13$ bol zároveň rezom pôvodným juhozápadným traktom paláca. Tento trakt už bol postavený vo svahu pod najvyššou skalnou plošinou. Aj vd’aka tomu sa tu pôvodná stratigrafia zachovala o čosi lepšie ako v severovýchodnom palácovom trakte. Výskumom sa $\mathrm{v}$ ňom podarilo zachytit' dobovú pochôdznu niveletu v tejto časti paláca (obr. 5), tvorenú silnou maltovou dlážkou, spevnenou drobnými kameňmi a vyhladenou na povrchu (obr. 6). Jej úroveň bola o takmer $200 \mathrm{~cm}$ nižšie ako najnižšia možná niveleta, ktorú v severovýchodnom

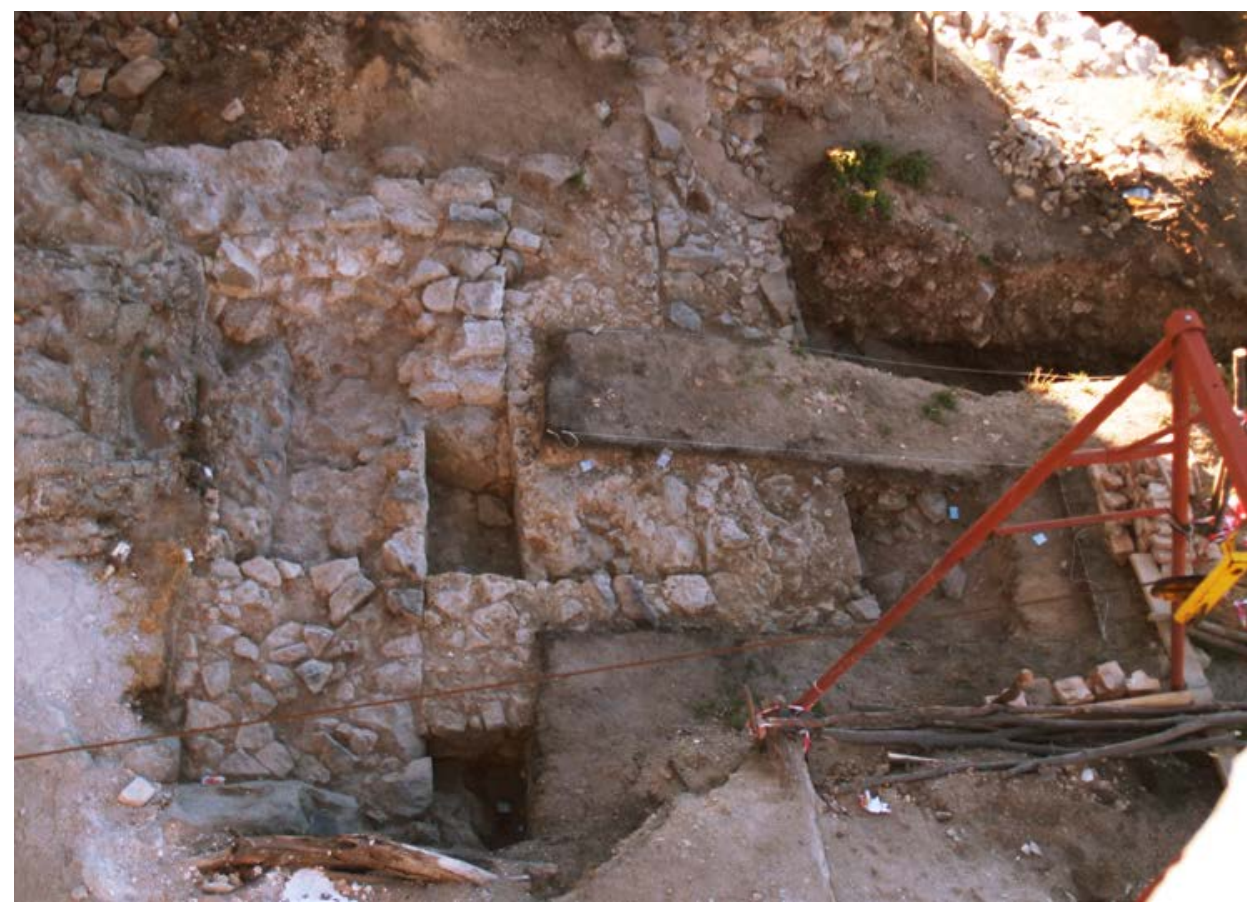

Obr. 3. Hrad Slanec, okr. Košice-okolie. Pohl’ad z veže juhovýchodným smerom. Múry paláca v sektore B sondy 1/13. Foto L. Trnkus.

Abb. 3. Burg Slanec, Bez. Košice-Umland. Blick vom Turm nach Südosten. Palasmauern in Sektor B von Sondierschnitt 1/13. Foto L. Trnkus. 
trakte dovol'uje vystupujúce skalné podložie (jej presnú úroveň a podobu nepoznáme). Dlážka v Reze 2 už nebola kompaktná, bola značne rozrušená. Jej úroveň korešpondovala s rozhraním odskoku a líca múru oddel'ujúceho trakty paláca (obr. 7, 18:M4a). Vo vrstve pod dlážkou bol zachytený nepočetný, no jednoliaty vrcholnostredoveký materiál. To dovol'uje v súvislosti s jej datovaním uvažovat' o jej zaradení už bud' do fázy výstavby paláca, prípadne k jeho stavebným úpravám spred roku 1400. Priamo na vrstve dlážky ležala rozsiahla stavebná deštrukcia, tvorená stavebnou keramikou a kameňmi. Stavebnú keramiku reprezentovalo viacero kusov plevových dlaždíc a minimálne dva druhy gotických prstovaných tehál (Čurný 2013). Najmä plevové dlaždice a tehly, tzv. „,buchty“, poukazujú na najstaršie stavebné fázy hradu. M. Čurný v analýze materiálu upozorňuje i na pravdepodobnú prítomnost' stĺpikových tehál v najstaršej architektúre hradu $(2013,7)$.

Rez 2 zachytil i priebeh vonkajšieho obvodového plášta paláca, ktorý využil hmotu bývalej najstaršej vnútornej hradby (obr. 18:M1). Priebeh muriva plášta bol okrem existujúcich nadzemných častí juhovýchodnej steny paláca zachytený ešte $\mathrm{v}$ mieste jeho juhozápadného nárožia i s viditel'ným zaoblením (sonda 9/13; obr. 18:M1) a tiež v sonde $12 / 13$, kde sa potvrdil predpoklad M. Šimkovica, že by sa tu pôvodná hradba mala pripájat' priamo na murivo veže (obr. 8) a že opevnenie dolného nádvoria severozápadne od veže už nesúvisí s najstaršou stavebnou fázou hradu, ale je mladšie.

$\mathrm{S}$ archeologickým výskumom jadra hradu Slanec súvisí ešte sonda 3/13. Bola umiestnená medzi stenu paláca a pôvodný parkánový múr. Čiastočne sa ňou podarilo preskúmat' priestor parkánu. Pôvodný povrch, tvorený skalným podložím, snád' i s odvodňovacím žlabom (obr. 9) niekedy v neskorom stredoveku nahradila murovaná pivnica, čím sa v pôvodnom parkáne musela výrazne navýšit' pochôdzna niveleta.

$\mathrm{K}$ odkrytiu fragmentov stredovekých kamenných murív došlo i v severovýchodnom susedstve paláca (sonda 14/13) a severovýchodne od veže (sonda 4/13). Ich dispozícia a interpretácia je však výzvou až pre nasledujúci výskum.

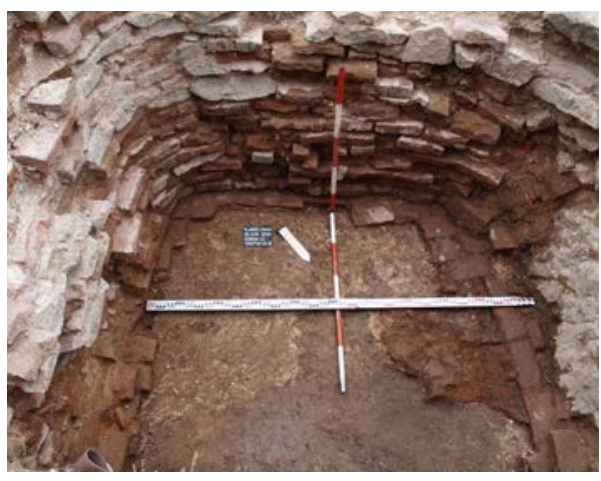

Obr. 4. Hrad Slanec, okr. Košice-okolie. Sektor C sondy 1/13. Pohl'ad na odkrytú tehlovo-kamennú plentu suterénu pod kaplnkou. Foto L. Trnkus.

Abb. 4. Burg Slanec, Bez. Košice-Umland. Sektor $C$ von Sondierschnitt 1/13. Blick auf die freigelegte Backstein-Stein-Verkleidung des Souterrains unter der Kapelle. Foto L. Trnkus.

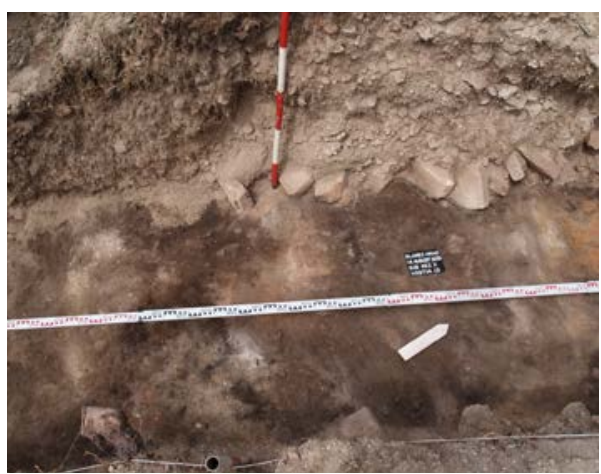

Obr. 5. Hrad Slanec, okr. Košice-okolie. Odkrytá úroveň s čiastočne zachytenou maltovou dlážkou v Reze 2. Foto L. Trnkus.

Abb. 5. Burg Slanec, Bez. Košice-Umland. Festgestelltes Höhenniveau mit teilweise festgestelltem Mörtelfußboden in Schnitt 2. Foto L. Trnkus.

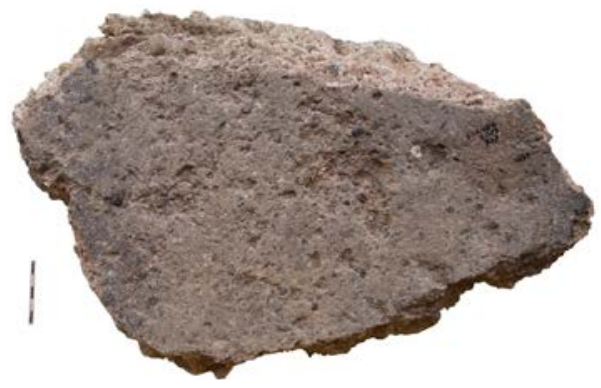

Obr. 6. Hrad Slanec, okr. Košice-okolie. Fragment silnej maltovej dlážky z Rezu 2. Foto R. Rusnák.

Abb. 6. Burg Slanec, Bez. Košice-Umland. Fragment des starken Mörtelfußbodens aus Schnitt 2. Foto R. Rusnák. 


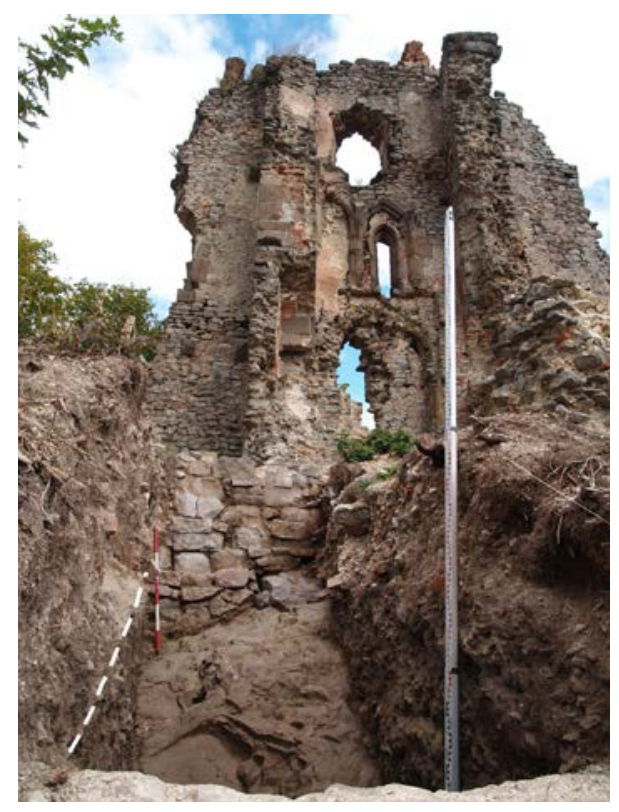

Obr. 7. Hrad Slanec, okr. Košice-okolie. Pohl'ad od juhozápadu na Rez 2 s naznačenou úrovňou dlážky, v pozadí zachovaný múr paláca. Foto R. Rusnák.

Abb. 7. Burg Slanec, Bez. Košice-Umland. Blick von Südwesten auf Schnitt 2 mit angedeutetem Höhenniveau des Fußbodens. Im Hintergrund erhaltenes Palasmauerwerk. Foto R. Rusnák.

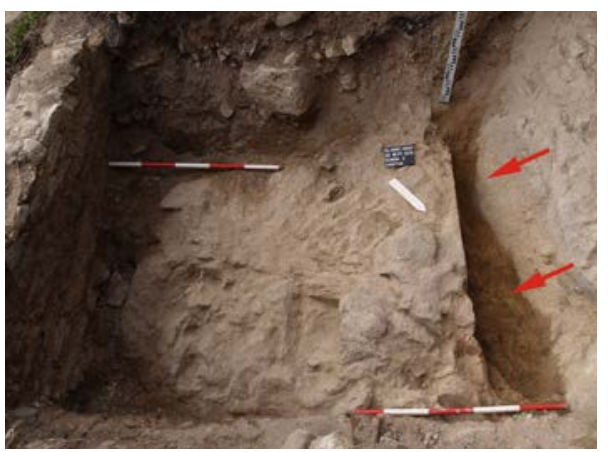

Obr. 9. Hrad Slanec, okr. Košice-okolie. Sonda 3/13. Odkryté skalné podložie s možným odvodňovacím rigolom (vyznačené šípkami). Foto R. Rusnák.

Abb. 9. Burg Slanec, Bez. Košice-Umland. Sondierschnitt 3/13. Freigelegter Felsenuntergrund mit möglichem Entwässerungsgraben (durch Pfeile angedeutet). Foto R. Rusnák.

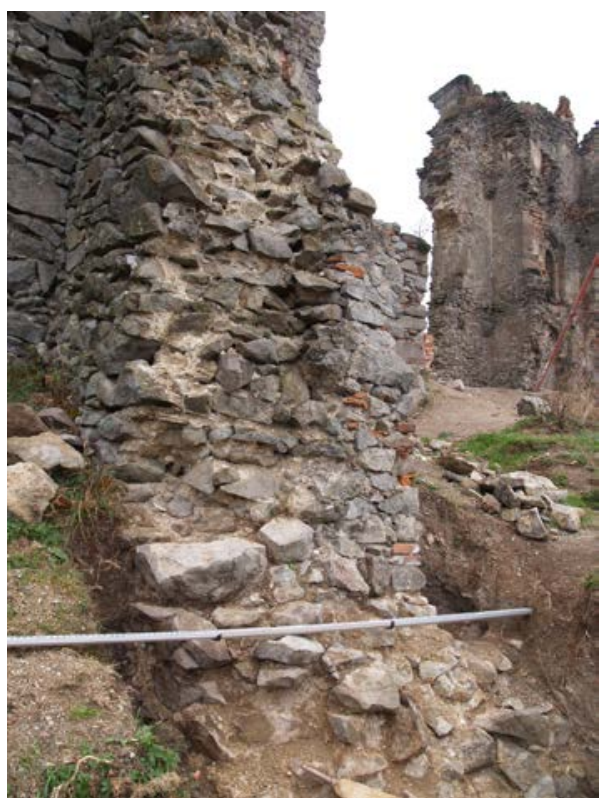

Obr. 8. Hrad Slanec, okr. Košice-okolie. Sonda 12/13. Odkryté napojenie najstaršej vnútornej hradby na vežu. Foto R. Rusnák.

Abb. 8. Burg Slanec, Bez. Košice-Umland. Sondierschnitt 12/13. Freigelegter Anschluss der ältesten Innenwehrmauer am Turm. Foto R. Rusnák.

Medzi hnutel’nými nálezmi z výskumu prevládali keramické črepy, fragmenty kachlíc či relatívne široký rad artefaktov stavebnej keramiky. Nálezy sprevádzali pozostatky železných predmetov i sporadické nálezy mincí. Drvivá väššina získaných nálezov bola vel’mi fragmentárna. S výnimkou stavebnej keramiky chýbajú skutočne výrazné, dobre zachované nálezy. Nálezy stavebnej keramiky priniesli obohatenie o viacero formátov plevových i kanelovaných tehál, dlaždíc i fragmenty škridlicovej strešnej krytiny.

Z chronologického hladiska bol medzi nálezmi najsilnejšie zastúpený horizont včasného novoveku, silné zastúpenie malo i obdobie neskorého stredoveku. Sporadicky sa zachytili i vrstvy patriace nálezom vrcholnostredovekého horizontu.

\section{Nové poznatky z architektonicko-historického výskumu}

Architektonicko-historické bádanie v rokoch 2012 a 2013 bolo zamerané na podrobný výskum hradnej veže a vyhodnotenie situácie odkrytej archeologickým výskumom. Výskum potvrdil predpoklad (Šimkovic 2003; Plaček-Bóna 2007), že v hmote dobre zachovanej vrcholnogotickej veže je takmer kompletne zachovaná staršia stavba s vnútorným priemerom približne 4,5 m 
a obvodovými múrmi hrubými 1,8 m (obr. 10,11, 18-21:M1). Novým poznatkom sú indície o zosilnení veže mohutnou plentou ešte pred vel'kou vrchnologotickou adaptáciou hradu. V rámci vel'kej vrchnologotickej prestavby hradu sa podoba veže výrazne zmenila jej začlenením do hmoty novovybudovaného paláca. Neskoršie úpravy priniesli len vybudovanie renesančných klenieb v interiéri. Po zániku hradu bola veža v roku 1815 obnovená a upravená na rozhladňu a malé múzeum.

Murivo najstaršej veže je v rámci mladšieho stredovekého plášt’a zachované takmer v celej pôvodnej hmote, siahajúcej do výšky približne $14 \mathrm{~m}$, teda do úrovne dnešného piateho podlažia. Vnútorné členenie pôvodnej stavby je možné aspoň v základných rysoch rekonštruovat'. Veža bola celkovo štvorpodlažná. Nízke suterénne podlažie bez otvorov bolo ukončené plochým trámovým stropom a prístupné bolo zrejme len otvorom v strope. Pôvodný vstup viedol do prvého nadzemného podlažia. Na severovýchodnej strane sa čiastočne zachoval pôvodný vstupný portál s torzom ostenia, položený vo výške približne 5 m nad terénom nádvoria (obr. 12, 19:A). Vstup mal na vonkajšej strane vysunutú drevenú podestu, ku ktorej pravdepodobne viedlo vonkajšie schodisko alebo ochodza. Nad vstupným prvým podlažím mala veža ešte d’alšie dve obytné podlažia, ukončené plochými stropmi. Druhé nadzemné podlažie bolo osvetlené minimálne jedným štrbinovým oknom s bočnými sedadlami v okennej nike (obr. 13, 20:D). Dvojicou rovnakých okien bolo osvetlené aj tretie podlažie veže (obr. 21:E, F). V ňom sa zachoval aj zvyšok d’alšieho, pravdepodobne dodatočne vytvoreného otvoru (obr. 21:G). Jeho pôvodná funkcia nie je vzhl’adom na zachovanú výšku (minimálne $3 \mathrm{~m}$ ) jasná. Nad tretím podlažím murivo veže ustupuje na hrúbku približne $60 \mathrm{~cm}$. Zachovaná výška múru $(1 \mathrm{~m})$ môže naznačovat', že ide o spodnú čast' obrannej predprsne na korune veže.

Interiér aj exteriér veže bol omietaný takmer identickou nahrubo nahodenou omietkou. Pre vežu je charakteristické diferencované využívanie stavebných materiálov. Obvodové murivo je stavané výlučne z lomového kameňa s prevahou vel'kých kusov v líci, pričom sú v ňom druhotne použité zlomky nízkych plevových tehál. Okná obytných miestností na druhom a tretom nadzemnom podlaží sú murované výlučne z tehál. Takéto diferencované využívanie stavebných

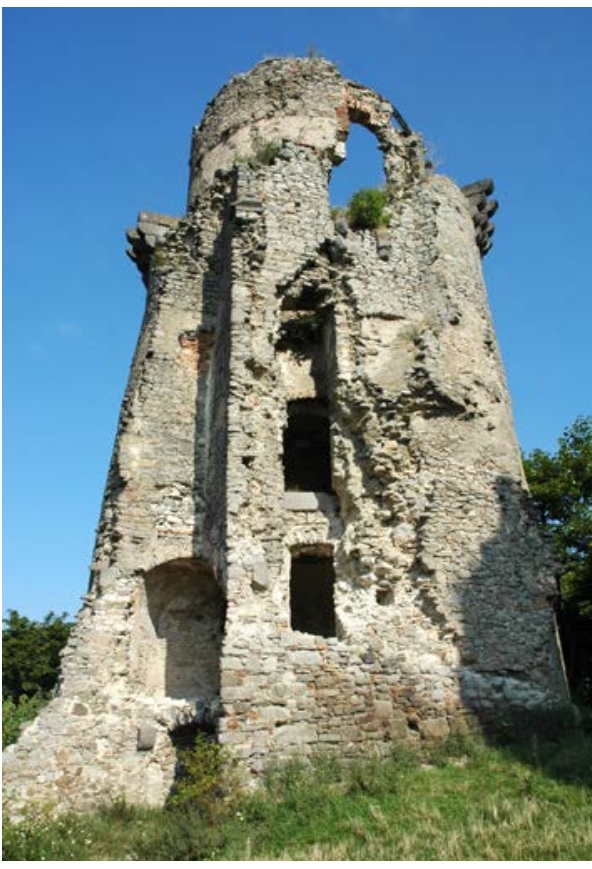

Obr. 10. Hrad Slanec, okr. Košice-okolie. Pohl'ad na hradnú vežu z nádvoria. Foto M. Slámka.

Abb. 10. Burg Slanec, Bez. Košice-Umland. Blick auf den Burgturm vom Hof aus. Foto M. Slámka.

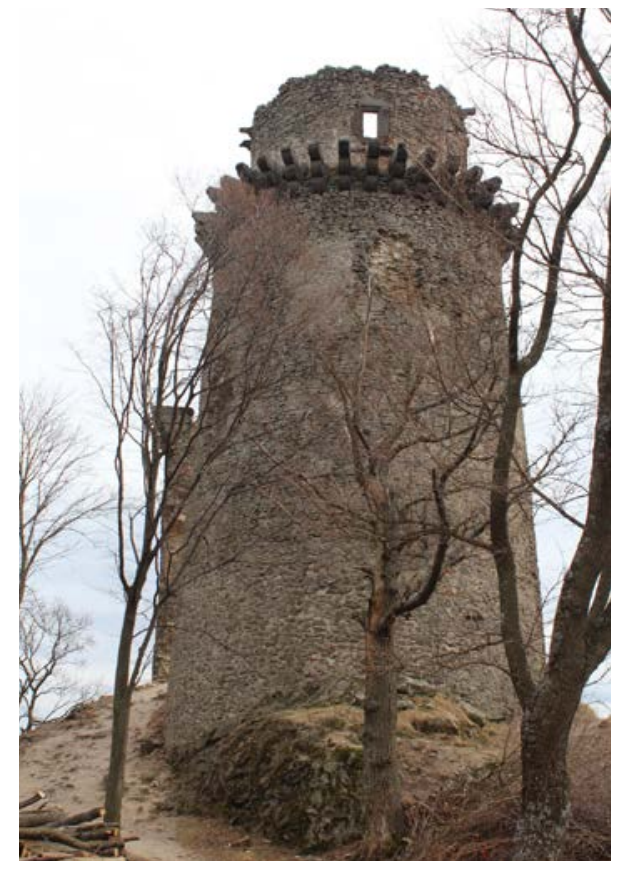

Obr. 11. Hrad Slanec, okr. Košice-okolie. Pohl'ad na hradnú vežu od severozápadu. Foto M. Šimkovic.

Abb. 11. Burg Slanec, Bez. Košice-Umland. Blick auf den Burgturm von Nordwesten. Foto M. Šimkovic. 


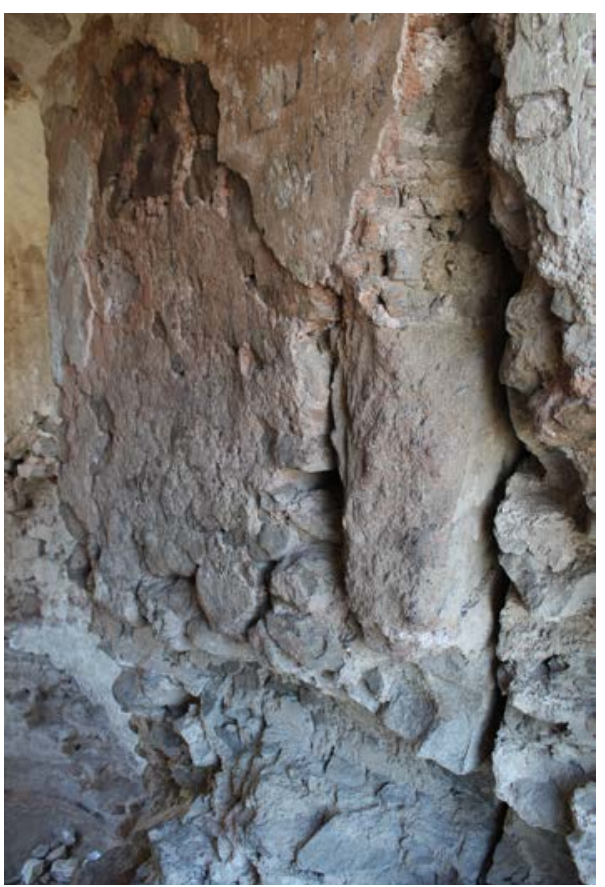

Obr. 12. Hrad Slanec, okr. Košice-okolie. Detail zvyšku ostenia pôvodného portálu veže. Foto M. Šimkovic.

Abb. 12. Burg Slanec, Bez. Košice-Umland. Detail der Laibung des ursprünglichen Turmportals. Foto M. Šimkovic. materiálov je doložené napríklad na románskom paláci hradu v Nitre, ale vo všeobecnosti je skôr charakteristické pre mladšie obdobie (napr. vrcholnogotická prestavba Slanca, hrad Vígl'aš).

Hradná veža bola ústrednou stavbou hradného areálu, ktorý bol opevnený hradbovým múrom s pôvodnou hrúbkou okolo 1,4 m. Pred realizáciou archeologického výskumu boli z hradby nad terénom zachované úseky múru na východnej, juhovýchodnej a západnej strane jadra hradu. Najlepšie zachovaný je východný úsek, kde v rámci steny mladšieho paláca stojí hradba v celej pôvodnej výške takmer $11 \mathrm{~m}$. Opevnenie bolo na hornej strane ukončené obrannou ochodzou s cimburím (obr. 14, 15, 17). Ďalší úsek hradby vystupuje nad terén na západnej strane. Čelný múr severozápadného traktu neskoršieho gotického paláca tvorí pôvodný hradbový múr, ktorý je zachovaný do úrovne približne $6 \mathrm{~m}$.

Priebeh a rozsah pôvodného opevnenia hradu takmer v celom rozsahu overil archeologický výskum v roku 2013. Sondy 1/13, 3/13, 9/13 a 12/13 odkryli priebeh pôvodnej obvodovej hradby na juhovýchodnej a juhozápadnej strane (obr. 18:M1). Významným

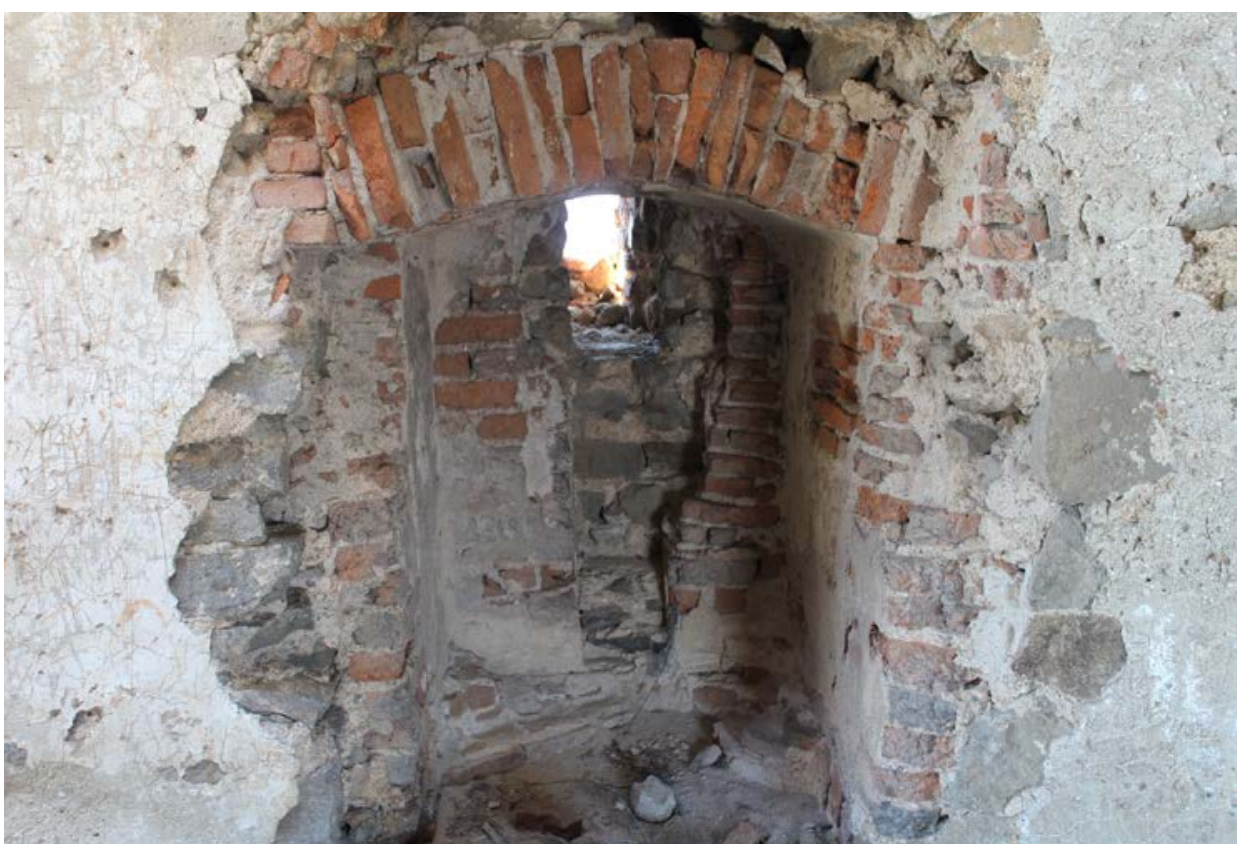

Obr. 13. Hrad Slanec, okr. Košice-okolie. Pôvodné okno na druhom podlaží veže. Foto M. Šimkovic.

Abb. 13. Burg Slanec, Bez. Košice-Umland. Ursprüngliches Fenster im zweiten Turmstockwerk. Foto M. Šimkovic. 


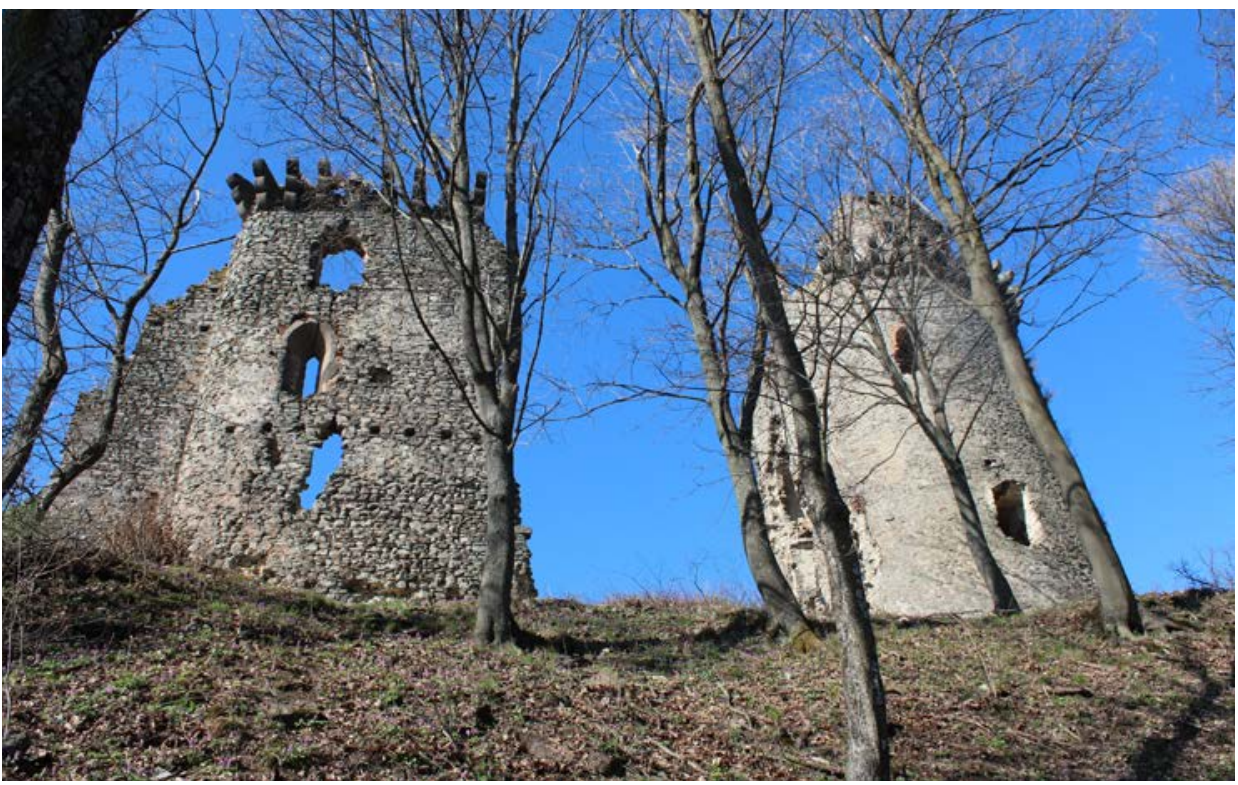

Obr. 14. Hrad Slanec, okr. Košice-okolie. Celkový pohl'ad na jadro s vežou a severovýchodnou stenou paláca so zachovaným murivom pôvodnej hradby. Foto M. Šimkovic.

Abb. 14. Burg Slanec, Bez. Košice-Umland. Gesamtblick auf die Kernburg mit Turm und nordöstlicher Palaswand mit erhaltenem Mauerwerk der ursprünglichen Wehrmauer. Foto M. Šimkovic.

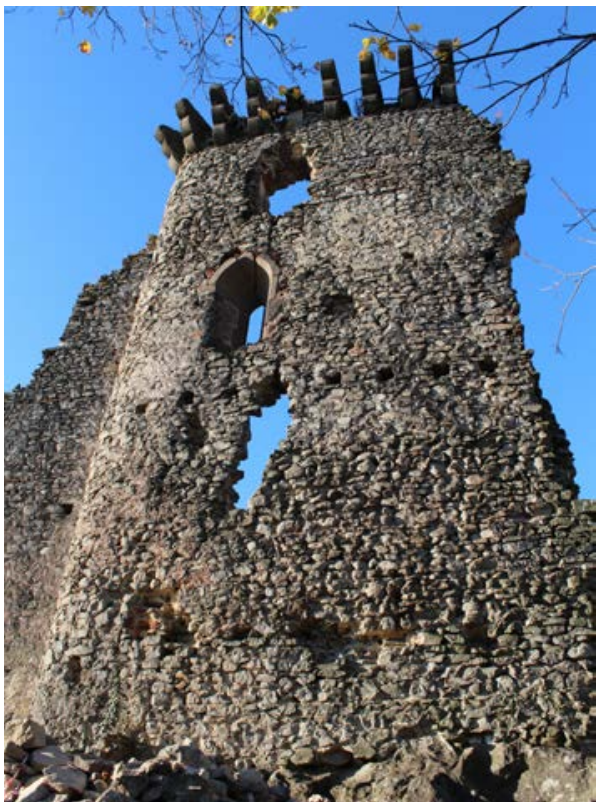

Obr. 15. Hrad Slanec, okr. Košice-okolie. Celkový pohl'ad na severovýchodný úsek steny paláca so zachovaným murivom pôvodnej hradby. Foto M. Šimkovic.

Abb. 15. Burg Slanec, Bez. Košice-Umland. Gesamtblick auf den nordöstlichen Abschnitt der Palaswand mit erhaltenem Mauerwerk der ursprünglichen Wehrmauer. Foto M. Šimkovic. nálezom je predovšetkým overenie zaobleného nárožia $\mathrm{s}$ nadväzujúcim úsekom hradby na južnej strane. Odkrytie západného nárožia potvrdilo, že k pôvodnému opevneniu patrí aj čast' zachovaného múru na juhozápadnej strane veže. Týmto tiež zaobleným nárožím sa hradba zalamovala a napájala sa $\mathrm{k}$ hradnej veži približne v strede jej juhozápadnej strany (obr. 8, 18:M1).

Otázna ostáva ešte podoba severnej strany opevnenia a predovšetkým jeho napojenie na vežu. Podl'a odtlačkov v murive veže bola severná stena mladšieho paláca $\mathrm{k}$ veži napojená šikmo, ale v tejto časti zrejme nerešpektuje priebeh staršieho opevnenia. Predpoklad o odlišnom priebehu pôvodnej hradby je možné opierat' predovšetkým o zistený pôvodný vstup na severovýchodnej strane prvého podlažia veže, ktorý smeruje mimo priestor gotického paláca (obr. 19:A).

Podl'a zachovaných detailov je zjavné, že na východnej strane bola $\mathrm{k}$ hradbe na vnútornej strane od počiatkov pristavaná stavba. O jej existencii vypovedajú dve štrbinové okienka v hmote hradbového múru (obr. 19:B, C) a zachované lôžka pôvodného trámového stropu (obr. 16). Pôdorysný rozsah stavby upresnila 


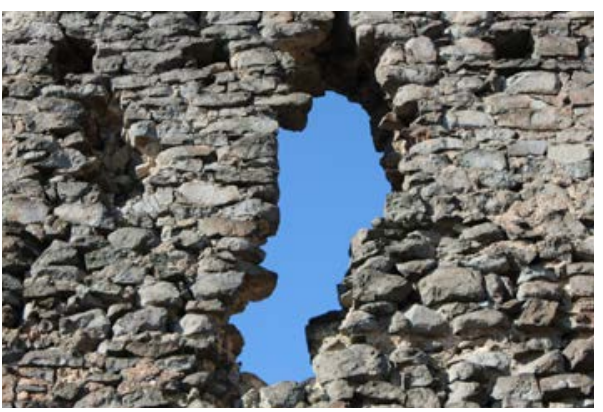

Obr. 16. Hrad Slanec, okr. Košice-okolie. Detail severovýchodnej steny paláca so zvyškom okna a lôžkami stropu pôvodnej budovy. Foto M. Šimkovic.

Abb. 16. Burg Slanec, Bez. Košice-Umland. Detail der nordöstlichen Palaswand mit Relikt eines Fensters und Deckenbalkenlagern des ursprünglichen Gebäudes. Foto M. Šimkovic.

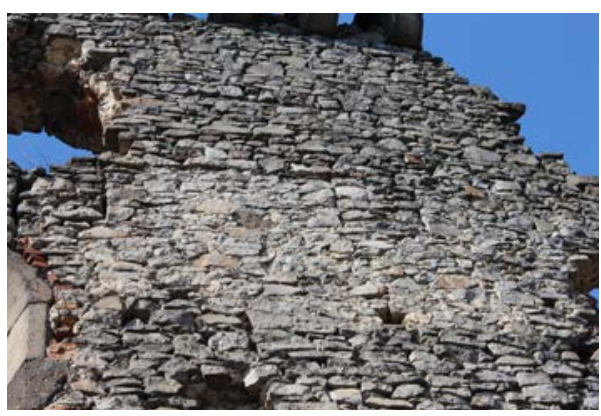

Obr. 17. Hrad Slanec, okr. Košice-okolie. Detail severovýchodnej steny paláca so zamurovaným cimburím a trámov ochodze. Foto M. Šimkovic.

Abb. 17. Burg Slanec, Bez. Košice-Umland. Detail der nordöstlichen Palaswand mit vermauerten Zinnen und Laufgangbalken. Foto M. Šimkovic.

archeologická sonda 1/2013, ktorá odkryla čast’ múru (obr. 3, 18:M1), ktorý je možné interpretovat' ako dvorovú stenu budovy pristavanej k vnútornej strane severovýchodnej hradby. Podl'a neho mala stavba vnútornú šírku 5,6 m, ostatné rozmery sa vd’aka narušeniu situácie nepodarilo overit'. Vnútorný priestor budovy osvetl'ovali dve malé štrbinové okienka (obr. 19:B, C), zachované v severovýchodnom a juhovýchodnom múre. Podl’a lôžok trámového stropu a zvyškov ochodze je možné predpokladat', že stavba bola jednopodlažná, zastropená trámovým stropom. Nad ním bola zrejme ukončená pultovou strechou, osadenou pod ochodzou hradby.

Celkovo je možné na základe aktuálneho stavu výskumu konštatovat', že opevnenie vymedzovalo plochu hradu v tvare takmer pravidelného obdížnika s rozmermi $19 \times 15 \mathrm{~m}$. Napriek dobre zachovanému severovýchodnému úseku opevnenia sú otázne výškové parametre hradby. Je pravdepodobné, že väčšina hradby bola nižšia ako zachovaný severovýchodný úsek. Výšku $11 \mathrm{~m}$ hradba dosahovala zrejme len na časti svojho priebehu, kde prekrývala prilahlú obytnú budovu. Výška hradbového múru okolo $12 \mathrm{~m}$ je doložená na hradoch Divín a Parič v Trebišove. Tu však hradbové múry plnia funkciu hlavnej obrannej stavby a svojou hmotou mali chránit' vnútornú zástavbu.

Z hl'adiska celkovej charakteristiky dispozície hradu bol Slanec považovaný za príklad tzv. bergfridovej dispozície (Plaček-Bóna 2007, 33). Tá je charakteristická vežou s dominantnou obrannou funkciou, ktorá je posunutá do čela hradu a obytnou budovou v chránenej polohe. Vo svetle aktuálnych výskumov sa však pôvodný hrad javí odlišne. Hradnú vežu s vnútorným priemerom viac ako 4 m a dvomi obytnými podlažiami môžeme skôr považovat' za ústrednú obytnú a obrannú stavbu hradu postavenú na najvyššom mieste hradného areálu. Vežu dopíňala budova vo východnej časti nádvoria, len t’ažko mohla plnit' funkciu hlavnej obytnej stavby hradu. Pravdepodobnejšie je, že mala len doplnkovú funkciu. Vznik najstaršieho hradu je možné datovat' na základe aktuálneho výskumu archívnych prameňov pred rok 1282. Zistená architektúra veže a opevnenia je v súlade s predpokladaným datovaním približne do tretiej štvrtiny 13. storočia.

Z vyhodnotenia nálezových situácií $\mathrm{v}$ sondách vyplýva, že súčastou pôvodného hradu z 13. storočia mohlo byt' predhradie, ktorého múr sa zachoval na juhovýchodnej strane (obr. 18:M2). Súčasné budovanie hradby s opevnením pôvodného hradu by mohla naznačovat' takmer identická štruktúra murív a predovšetkým vzájomné previazanie ich obvodovej hradby jadra a hradbového múru zistené v sonde 9/13. Podl'a zachovaných zvyškov muriva hradba vytvárala na juhovýchodnej strane ca 4 m široký parkán, ktorý sa na severovýchodnej strane zrejme rozširoval do približne $10 \mathrm{~m}$ širokého nádvoria. Hradba môže byt' zvyškom rozsiahlejšieho predhradia, ktorého rozsah a funkciu za súčasného stavu poznania je t’ažko bližšie charakterizovat'. Pravdepodobne súvisí s ochranou pôvodnej prístupovej cesty, ktorá mohla do hradu vstupovat' na severnej strane a potom pozdíž opevnenia pokračovat' do koridoru na juhovýchodnej strane, kde mohla byt' brána do hradného jadra. 


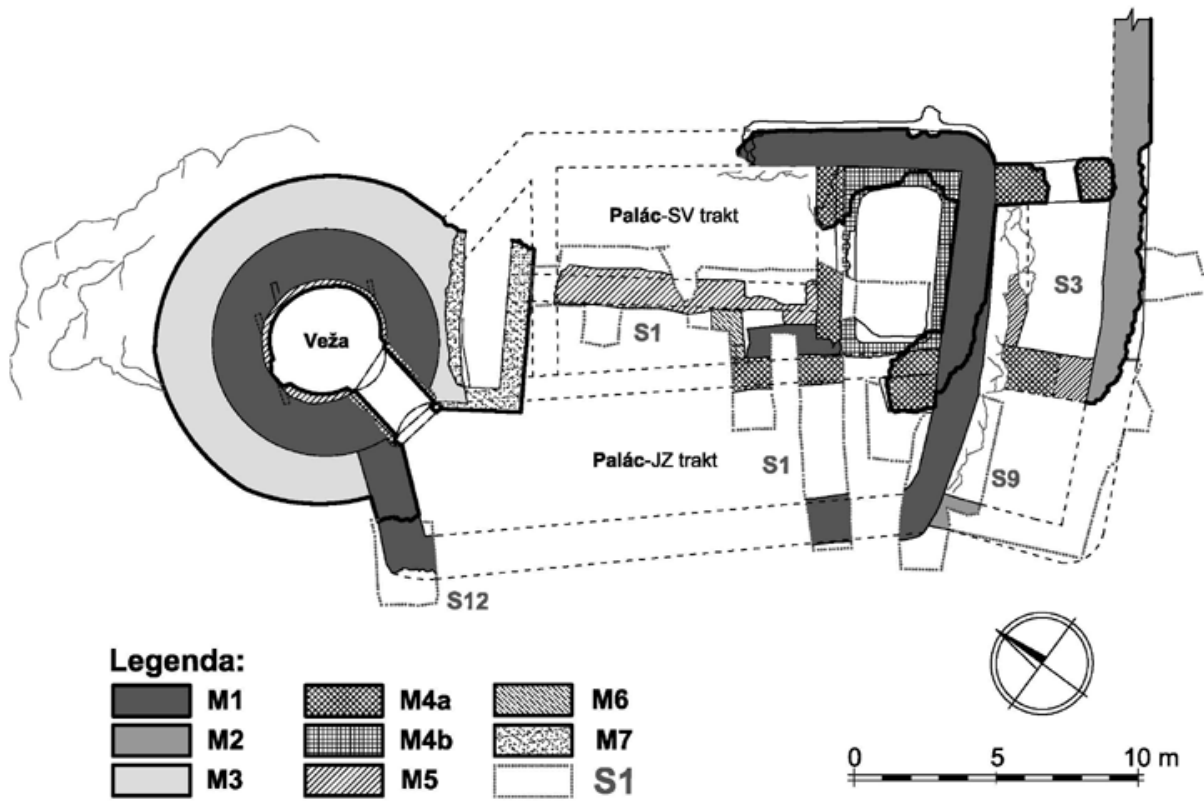

Obr. 18. Hrad Slanec, okr. Košice-okolie. Pôdorys hradného jadra v úrovni suterénu veže a archeologických sond. M1 13. storočie, pred rokom 1282; M2 - pravdepodobne 13. storočie; M3 - 14. storočie; M4a,b - koniec 14. storočia; M5, 6 16.-17. storočie; M7 - rok 1815; S1 - označenie sond archeologického výskumu z roku 2013. Kresba M. Šimkovic.

Abb. 18. Burg Slanec, Bez. Košice-Umland. Grundriss der Kernburg in Höhe des Turmsouterrains und der gelegten archäologischen Sondierschnitten. M1 - 13. Jhdt., vor 1282; M2 - wahrscheinlich 13. Jhdt.; M3 - 14. Jhdt.; M4a,b - Ende 14. Jhdt.; M5, 6 - 16.-17. Jhdt.; M7 - Jahr 1815; S1 - Kennzeichnung der archäologischen Sondiergrabungen von 2013. Zeichnung M. Šimkovic.

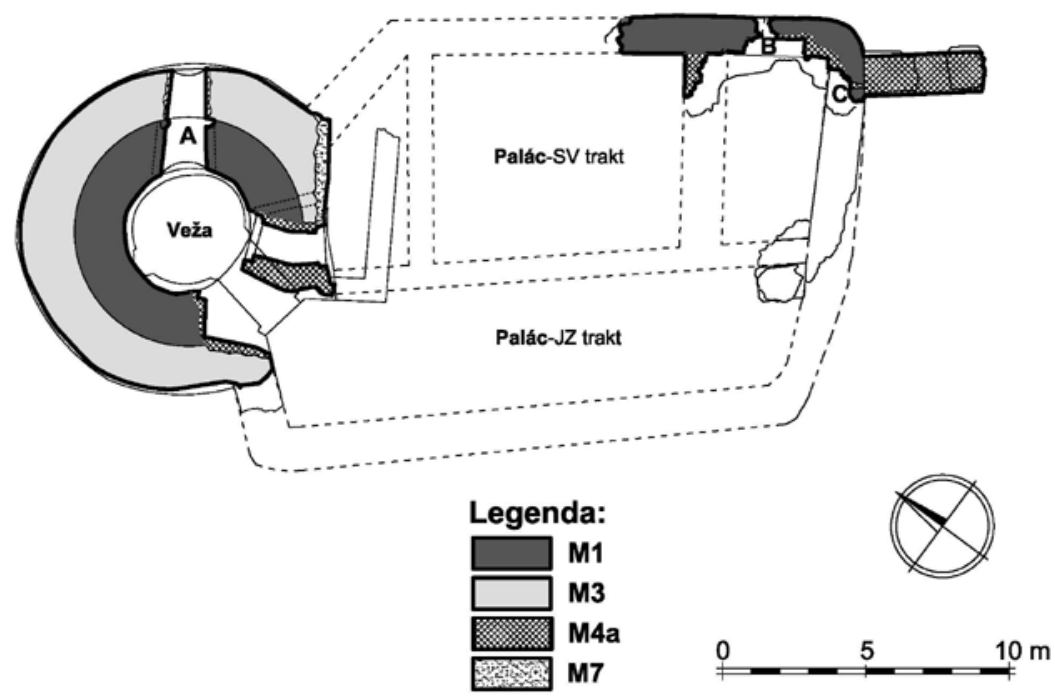

Obr. 19. Hrad Slanec, okr. Košice-okolie. Pôdorys hradného jadra v úrovni prvého podlažia veže a paláca. M1 - 13. storočie, pred rokom 1282; M3 - 14. storočie; M4a - koniec 14. storočia; M7 - rok 1815. Kresba M. Šimkovic.

Abb. 19. Burg Slanec, Bez. Košice-Umland. Grundriss der Kernburg in Höhe des ersten Turmstockwerks und des Palas. M1 - 13. Jhdt., vor 1282; M3 - 14. Jhdt.; M4a - Ende 14. Jhdt.; M7 - Jahr 1815. Zeichnung M. Šimkovic. 


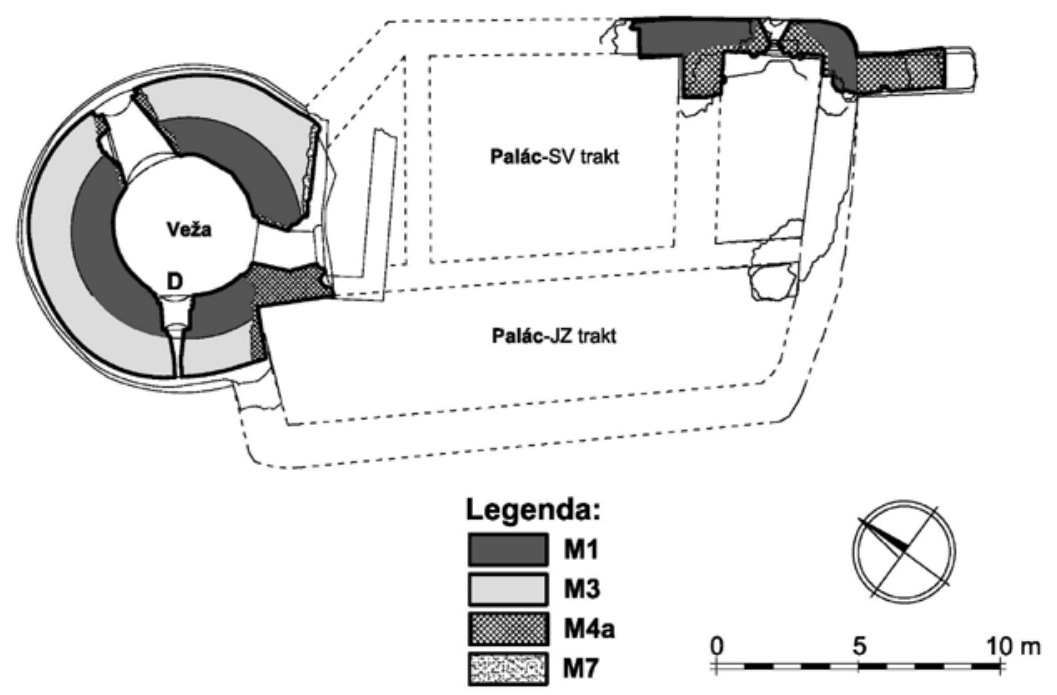

Obr. 20. Hrad Slanec, okr. Košice-okolie. Pôdorys hradného jadra v úrovni druhého podlažia veže a paláca. M1 - 13. storočie, pred rokom 1282; M3 - 14. storočie; M4a - koniec 14. storočia; M7 - rok 1815. Kresba M. Šimkovic.

Abb. 20. Burg Slanec, Bez. Košice-Umland. Grundriss der Kernburg in Höhe des zweiten Turmstockwerks und des Palas. M1 - 13. Jhdt., vor 1282; M3 - 14. Jhdt.; M4a - Ende 14. Jhdt.; M7 - Jahr 1815. Zeichnung M. Šimkovic.

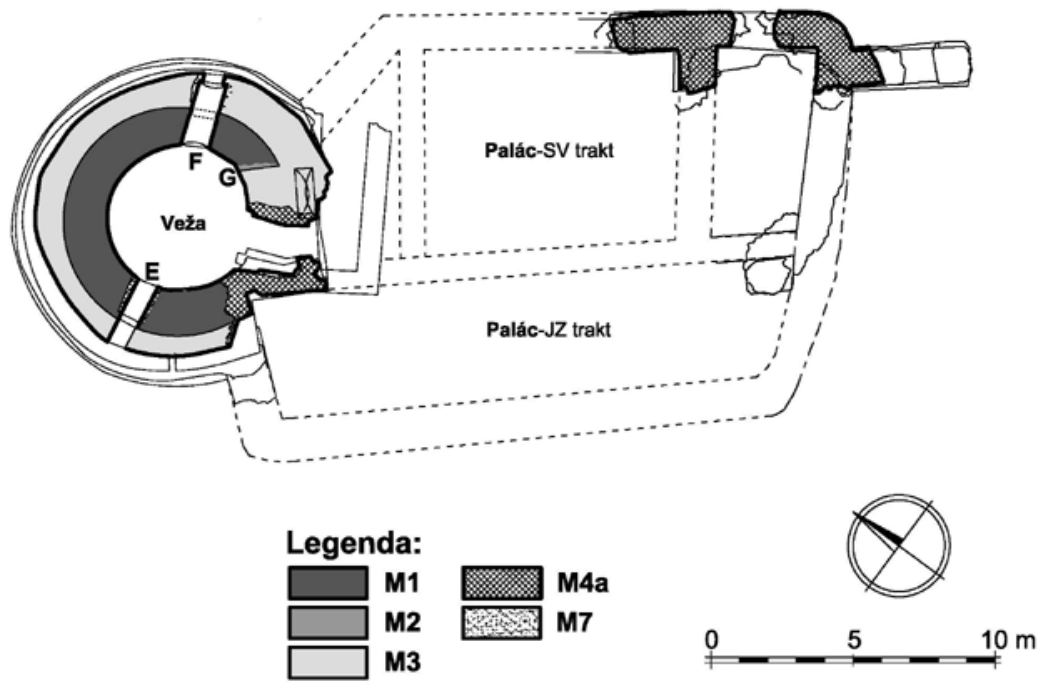

Obr. 21. Hrad Slanec, okr. Košice-okolie. Pôdorys hradného jadra v úrovni tretieho podlažia veže a paláca. M1 - 13. storočie, pred rokom 1282; M2 - pravdepodobne 13. storočie; M3 - 14. storočie; M4a - koniec 14. storočí; M7 - rok 1815. Kresba M. Šimkovic.

Abb. 21. Burg Slanec, Bez. Košice-Umland. Grundriss der Kernburg in Höhe des dritten Turmstockwerks und des Palas. M1 13. Jhdt., vor 1282; M2 - wahrscheinlich 13. Jhdt.; M3 - 14. Jhdt.; M4a-Ende 14. Jdht.; M7 - Jahr 1815. Zeichnung M. Šimkovic. 
Archeologický výskum tiež upresnil vnútorné dispozičné riešenie hradného paláca po vel'kej gotickej prestavbe realizovanej Ladislavom z Lučenca po roku 1387. Do nádvoria pôvodného hradu bol vstavaný hradný palác, ktorý ako obvodové múry využil pôvodnú hradbu (Šimkovic 2003). Zachovaná situácia na juhovýchodnej strane veže spolu s Myskovszkého pôdorysom z roku 1878 umožňovali predpokladat', že palác bol pozdížne členený na dva trakty, orientované na juhozápad a severovýchod. Tento predpoklad potvrdil nález muriva v sonde 1/13, ktoré polohou nadväzuje na zachované nadzemné torzo medzitraktového múru, zachované dodnes v rámci hmoty hradnej veže (obr. 18:M4a). V severovýchodnom trakte bezprostredne pri veži boli priechodné miestnosti s portálmi do susedného traktu paláca a do jednotlivých podlaží veže. Podstatnú čast' traktu tvorila jeho stredná čast's rozmermi ca $9 \times 6 \mathrm{~m}$. Tu boli v troch úrovniach nad sebou zoradené plochostropé miestnosti. Hlavným reprezentačným priestorom bola asi miestnost' na druhom podlaží s trámovým stropom na profilovaných konzolách. Na juhovýchodnej strane trakt ukončovala hradná kaplnka, ktorá výškovo prechádzala cez dve podlažia paláca a nad ňou bola ešte obytná miestnost's krbom. Sonda čiastočne odkryla aj priestor pod kaplnkou (obr. 18:M4b), ktorý býva v literatúre označovaný ako krypta (Slivka-Vallašek 1991, 196). Jeho obvod lemuje dodatočne vybudovaná plenta s vysokým podielom tehál a na povrchu upravená kvalitne vyhladenou omietkou s tehlovou drvou. Napriek zistenej cezúre celkové vyhodnotenie situácie a vzt’ahov murív dokladá, že obmurovanie suterénu pod kaplnkou je súčastou vrcholnogotickej prestavby hradu. Kvalitná omietka na povrchu líca naznačuje možnú interpretáciu priestoru ako cisterny.

Podla nálezovej situácie v sonde 1/13-R2 bol juhozápadný trakt paláca ca 4,7 m široký a jeho podlaha bola položená približne o 1,5 až $2 \mathrm{~m}$ nižšie ako podlaha severovýchodného traktu. O jeho vnútornom členení máme len skromné vedomosti. Podl'a zachovaných zvyškov obvodových múrov na severozápadnej strane pri veži boli priestory spodného podlažia prekryté trámovými stropmi, osadenými na kamenných konzolách.

Renesančné úpravy len v minimálnej miere zmenili podobu stredovekého hradu. $\mathrm{Z}$ doterajších výskumov vyplynulo, že v rámci renesančných úprav bola čast’ trámových stropov veže a paláca nahradená klenbami. Ich vybudovanie si v niektorých miestnostiach juhozápadného palácového traktu vyžiadalo posun úrovne pôvodných podlaží. Vedomosti o renesančných prestavbách dokresl'uje murivo odkryté v strednej časti sondy 1/13 (obr. 18:M5), Pravdepodobne je pozostatkom novej priečky, ktorá v strede paláca vyčlenila pozdíž pôvodnej medzitraktovej steny chodbu smerujúcu do kaplnky.

\section{Záver}

Výskumy realizované na hrade Slanec v priebehu rokov 2012-2014 významne prispeli k poznaniu podoby stredovekého hradu. Aktuálne datovanie jeho výstavby sa opiera predovšetkým o výpoved' písomných prameňov. Ich vyhodnotenie umožňuje datovat' vznik hradu pred rok 1282 a za jeho stavitel'a považovat' Petra zo Slanca. Do tohto obdobia je možné za súčasného stavu poznania datovat' najstaršiu zistenú podobu hradu s valcovou obytnou vežou na najvyššom mieste hradného vrchu a nádvorím s menšou budovou na chránenej juhovýchodnej strane. Dispozícia pôvodného hradu a jeho zachované architektonické detaily, ako sú okná veže a štrbinové okná budovy, sú v súlade s uvažovaným datovaním výstavby Slanca do 13. storočia. Významnú premenu v dejinách hradu predstavuje vel'korysá vrcholnogotická prestavba z konca 14. až začiatku 15. storočia. Na základe historických prameňov je možné jej realizáciu hodnoverne pripísat' dvorskému rytierovi král'a Ludovíta z Anjou, Ladislavovi z Lučenca. Pravdepodobne už krátko po získaní hradu v roku 1387 premenil pôvodné nevel'ké sídlo na vel'ký gotický palác. Ladislavova prestavba zásadným spôsobom určila podobu hradu. Ďalšie prestavby sa realizovali predovšetkým v priestore predhradia a hradné jadro zmenili len v minimálnej miere. Ďalšie poznatky o vrcholnogotickej prestavbe a d’alších stavebných úpravách hradu je možné očakávat' od pokračujúceho architektonicko-historického a archeologického výskumu hradu. 


\section{Pramene a literatúra}

AO XIII: Anjou-kori oklevéltár XIII, 1329 (Almási, T., ed.). Budapest - Szeged 2003.

AO XIV: Anjou-kori oklevéltár XIV, 1330 (Almási, T.-Köfalvi, T., edd.). Budapest - Szeged 2004.

AO XIX: Anjou-kori oklevéltár XIX, 1335 (Kristó, Gy.-Makk, F., edd.). Budapest - Szeged 2004.

AO XXXI: Anjou-kori oklevéltár XXXI, 1347 (Sebők, F., ed.). Budapest - Szeged 2007.

BO I: Oklevéltár a Tomaj nemzetségbeli losonczi Bánffy család történetéhez I, 1214-1457 (Varjú, E., ed.). Budapest 1908.

BO II: Oklevéltár a Tomaj nemzetségbeli losonczi Bánffy család történetéhez II, 1458-1526 (Iványi, B., ed.). Budapest 1928.

ČURNÝ, M., 2013: Slanec, okr. Košice-okolie, hrad Slanec. Vyhodnotenie nálezov stavebnej keramiky z archeologického výskumu v roku 2013. Odborný posudok k VS Rusnák, R.-Trnkus, L., Slanský hrad, zámer obnovy, ulož. v Archíve AÚ SAV Nitra.

ENGEL, P., 1996: Magyarország világi archontológiája 1301-1457 [DVD-ROM]. Budapest.

- 2002: Középkori magyar genealógia [DVD-ROM]. Budapest.

GARDAVSKÝ, Z., 1971: Srovnávací výzkum východoslovenských hradů, SÚRPMO Praha, pracoviště Olomouc, nestr.

Genealogická tabul'ka rodu Losonczy [on-line]. Dostupné z: http://www.genealogy.euweb.cz/hung/ losoncz.html, cit. 10. 2. 2015.

Genealogická tabul'ka rodu Forgách [on-line]. Dostupné z: http://www.genealogy.euweb.cz/hung/forgach4.html, cit. 10. 2. 2015.

Genealogická tabul'ka rodu Forgách [on-line]. Dostupné z: http://www.genealogy.euweb.cz/hung/forgach6.html, cit. 10. 2. 2015.

MENCLOVÁ, D., 1974: Príspevok k typológii hradov, zámkov a kaštiel’ov na Slovensku. In: Pisoň, Š., Hrady, zámky a kaštiele na Slovensku, 409-410. Martin.

MENCLOVI, V. a D., 1938: O účasti Slovenska na vzniku pozdněgotické architektury. Umění XI, 363-384.

MNL - OL, DL: Magyar Nemzeti Levéltár - Országos Levéltár, fond Diplomatikai levéltár, sign. DL 867, DL 14834, DL 82065, DL 27077, DL 82483, DL 82606, DL 90884, DL 82439, DL 90810, DL 64051.

MNL - OL, LRa: Magyar Nemzeti Levéltár, fond Magyar Kancelláriai Levéltár, Libri regii 5, pag. 441-443, $702-704$.

MNL - OL, LRb: Magyar Nemzeti Levéltár, fond Magyar Kancelláriai Levéltár, Libri regii 11, pag. 416-418.

MNL - OL, LRc: Magyar Nemzeti Levéltár, fond Magyar Kancelláriai Levéltár, Libri regii 23, pag. $257-259$.

MNL - OL, P 287a: Magyar Nemzeti Levéltár - Országos Levéltár, fond Forgách család gácsi ága lajstromozott iratok, fasc. T, no. 12, 18, doboz 25.

MNL - OL, P 287b: Magyar Nemzeti Levéltár - Országos Levéltár, fond Forgách család gácsi ága lajstromozott iratok, fasc. E, no. 1, 12, 19, 32, doboz 8.

MNL - OL, P 287c: Magyar Nemzeti Levéltár - Országos Levéltár, fond Forgách család gácsi ága lajstromozott iratok, fasc. B, no. 213, doboz 4.

MNL - OL, P 287d: Magyar Nemzeti Levéltár - Országos Levéltár, fond Forgách család gácsi ága lajstromozott iratok, fasc. T, no. 63, doboz 26.

MNL - OL, UCa: Magyar Nemzeti Levéltár - Országos Levéltár, fond Urbaria et conscriptiones, fasc. 12, no 29, pag. $1,2,4,6,9,11,13,15,18,22,24,26,31$.

MNL - OL, UCb: Magyar Nemzeti Levéltár - Országos Levéltár, fond Urbaria et conscriptiones fasc. 56, no 20, pag. 1, 2, 17, 18, 19-24, 30-38.

MNL - OL, UCc: Magyar Nemzeti Levéltár - Országos Levéltár, fond Urbaria et conscriptiones, fasc. 116, no. 27, pag. 32-37.

MNL - OL, UCd: Magyar Nemzeti Levéltár - Országos Levéltár, fond Urbaria et consriptiones, fasc. 54, no. 73 , pag. 2 .

MNL - OL, UCe: Magyar Nemzeti Levéltár - Országos Levéltár, fond. Urbaria et conscriptiones, fasc. 54, no. 74, pag. 1-3.

PLAČEK, M.-BÓNA, M., 2007: Encyklopédia slovenských hradov. Bratislava.

PO III: A podmanini Podmaniczky-család oklevéltára III, 1538-1549 (Lukinich, I., ed.). Budapest 1941.

RDSL: Regesta diplomatica nec non epistolaria Slovaciae I (Sedlák, V., ed.). Bratislava 1980.

SLIVKA, M., 1981: Príspevok k dejinám a výstavbe hradu Slanec, Nové obzory 23, 125-126.

SLIVKA, M.-VALLAŠEK, A., 1991: Hrady a hrádky na východnom Slovensku. Košice.

SZLUHA, M., 2000: Liptó vármegye nemes családjai. Budapest.

- 2007: Felvidéki nemes családok I. Trencsén vármegye. Budapest. 
ŠIMKOVIC, M., 2003: Slanec (katalógové heslo). In: Gotika. Dejiny slovenského výtvarného umenia (Buran, D., ed.), 594-595. Bratislava.

ŠIMKOVIC, M.-BÓNA, M., 2003. Hradná architektúra počas vlády Žigmunda Luxemburského. In: Gotika. Dejiny slovenského výtvarného umenia (Buran, D., ed.), 201-202. Bratislava.

ŠIMKOVIC, M.-JANURA, T., 2012: Hrad Slanec NKP. Architektonicko-historický výskum - 1. etapa. Výskumná dokumentácia ulož. v Archíve KPÚ Košice.

ZsO I: Zsigmondkori oklevéltár I, 1387-1399 (Mályusz, E., ed.). Budapest 1951.

\section{Zusammenfassung}

\section{Neue Erkenntnisse aus den an Burg Slanec durchgeführten Grabungen}

Im vorliegenden Beitrag werden auf Grundlage der aktuellen Grabungen neue Erkenntnisse über die ostslowakische Burg Slanec präsentiert. Die Burg ließ Peter von Slanec - der Begründer des Slanecer Zweiges des Hauses Abo - irgendwann vor dem Jahr 1282 errichten. Die zu ihr gehörende Grundherrschaft bestand aus fünf Dörfern, was kein besonders großes Potenzial für den Bau einer großräumigeren Burg darstellte. Die Nachkommen von Peter von Slanec überließen die Burg im Jahr 1330 Wilhelm Drugeth im Austausch gegen ein Dorf im Komitat Sáros. Nach Drugeths Tod blieb die Burg bis Ende des 14. Jahrhunderts in königlicher Hand. Am 25. Juli 1387 machte Königin Maria von Anjou die Burg Ladislaus von Lučenec († 1395) für seine Verdienste an ihrer Befreiung aus der Gefangenschaft im dalmatinischen Novigrad zum Geschenk. Ladislaus bekleidete dann nacheinander die Funktion des Bans von Severin und Bans von Matschwa, und der Höhepunkt seiner Karriere war die Verleihung des Titels Ban von Slawonien. Er hielt sich häufig auf dem Königshof auf, und da er außer Slanec keine andere Burg besaß, ließ er sie in einem ausgeprägt gotischen Stil umbauen.

Die Nachkommen von Ladislaus von Lučenec erwarben im Laufe des 15. Jahrhunderts auf ungarischem Territorium nach und nach weitere Burgen, was dazu führte, dass Slanec seine Funktion als Hauptresidenz der Familie verlor, aufgrund dessen die Burg ihr Aussehen ohne einschneidendere spätere Änderungen beibehielt. Zu Zeiten von Siegismund Lossonczy († vor 1523) wurde irgendwann zwischen 1521 und 1523 mit einem auch schriftlich belegten Umbau begonnen, der erst unter Sigismunds Witwe Katharina von Dóczy beendet wurde. Die Witwe leitete die Bauarbeiten mit der Hilfe von Kastellan Chapy, dem sie am 13. Mai 1523 einen Brief schrieb, er solle all das besorgen, was für die laufenden Bauarbeiten nötig sei. Im Zusammenhang mit der Fertigstellung der Zisterne, deren Bau noch von ihrem Gatten begonnen wurde, machte sie ihn darauf aufmerksam, dass keine Untertanen an Steinmetzarbeiten beteiligt werden sollten.

Nach dem Tod von Sigismund Lossonczy residierte dessen Sohn Stefan Lossonczy († 1553) auf der Burg und unternahm von ihr aus Raubzüge in die Stadt Kaschau (Košice). Gemäß einer Vereinbarung übergab Stefan die Burg noch vor 1538 gemäß seinem Bruder Anton Lossonczy, der sie auf Beschluss Ferdinands I. zerstören ließ. Mit Stefans Tochter Anna Lossosnczy († 1595) starb das Geschlecht der Lossonczys aus, und wegen ihrer Vermählung mit Baron Siegismund Forgács ging ein Teil der Slanec zurückgegebenen Besitztümer auf die Familie Forgácz über. Von ihnen wurde die Burg nicht als ständiger Sitz genutzt. Während des Aufstands von Emmerich Thököly wurde Burg Slanec zerstört und nicht wieder aufgebaut. Erst unter Graf Josef Forgácz $(* 1763, \dagger 1832)$ kam es zu einem teilweisen Wiederaufbau der Ruine. Im Jahr 1815 ließ er den Turm instandsetzen und eine Inschrifttafel anbringen. Josefs Sohn Graf Nikolaus Forgácz (* 1784, † 1857) ließ sich in der Gemeinde Slanec nieder, wo er das Schloss unterhalb der Burgruine klassizistisch umbauen und einen Park anlegen ließ. Wahrscheinlich ließ er die Ruine als romantische Komponente in den Park einfügen, was ihre regelmäßige Instandhaltung zur Folge hatte.

Die archäologische Saison 2013 verlief auf Burg Slanec parallel zu den Bauarbeiten, die im Rahmen einer geplanten schrittweisen Revitalisierung mehrerer Burgarchitekturen erfolgten. Die meiste Aufmerksamkeit wurde der Kernburg entgegengebracht, aus archäologischer Sicht 
war es eine Herausforderung, sich in ihrer baulichen Entwicklung besser orientieren und ohne erhalten gebliebene oberirdische Teile den Verlauf der Gemäuer sowie das damalige Gehniveau identifizieren zu können. Es gelang, eine ganze Reihe Überreste von Stein-, bzw. Stein-Ziegel-Bauten freizulegen (Abb. 3).

In Sektor 1C/13 wurde ein Raum freigelegt, der mit hoher Wahrscheinlichkeit in den Felsenuntergrund gehauen wurde, dessen Wände überwiegend aus Backsteinen bestanden und nur stellenweise mit Bruchsteinen ausgefüllt waren (Abb. 4). Bei den Wänden war fragmentarisch auch der Backsteinboden erhalten geblieben.

Schnitt R2 von Sondierschnitt 1/13 war zugleich auch ein Schnitt durch den ursprünglichen südwestlichen Trakt des Palas. Durch die Grabung gelang es, den Höhenverlauf der Gehfläche in diesem Teil des Palas festzustellen (Abb. 5) Sie bestand aus einem starken, mit kleinen Steinen befestigtem Mörtelfußboden mit glatter Oberfläche (Abb. 6).

Die aktuelle bauhistorische Untersuchung konzentrierte sich vor allem auf den Bau des gut erhaltenen Burgturms. Das Mauerwerk des ältesten Turms ist im Rahmen der jüngeren mittelalterlichen Außenmauern fast in seiner gesamten ursprünglichen Baumasse erhalten. Der Burgturm war der zentrale Bau des mit einer ursprünglich ca. 1,4 m starken Wehrmauer befestigten Burgareals. Verlauf und Umfang der ursprünglichen Befestigung der Burg wurde von der 2013 durchgeführten archäologischen Grabung fast im gesamten Ausmaß verifiziert. Insgesamt kann aufgrund des derzeitigen Forschungsstandes festgehalten werden, dass die Befestigung eine Burgfläche umgrenzte, welche die Form eines fast regelmäßigen Rechtecks mit den Maßen $19 \times 15 \mathrm{~m}$ hatte. Durch die archäologische Grabung wurde auch die innere Disposition des Burgpalas nach dem von Ladislaus von Lučenec nach 1387 durchgeführten Umbau sowie der Umfang der jüngeren Renaissanceumbauten der Burg präzisiert.

Mgr. Tomáš Janura, PhD., Historický ústav SAV, P. O. Box 198, Klemensova 19, SK 81499 Bratislava, Slovenská republika, histjanu@savba.sk

Mgr. Rastislav Rusnák, PhD., Fakulta umení Technickej univerzity v Košiciach, Letná 9, SK 04200 Košice, Slovenská republika, rastislav.rusnak@hotmail.sk

Mgr. Michal Šimkovic, Kimovská 4, SK 96001 Zvolen, Slovenská republika, simkovic.miso@gmail.com

Mgr. Lukáš Trnkus, Nová 5, SK 97404 Banská Bystrica, Slovenská republika,lukas.trnkus@gmail.com 